\title{
$\mathbb{Z}$ Iuke $\mathfrak{Z}$ aw $\mathfrak{J}$ ournal
}

VoLUME 1965

AUTUMN

NUMBER 4

\section{AMERICAN FATAL ACCIDENT STATUTES-PART I: THE LEGISLATIVE BIRTH PAINS}

\author{
Wex S. MaLone*
}

IN AN 1808 decision at Nisi Prius, ${ }^{1}$ Lord Ellenborough stated bluntly, without bothering to give an explanation, that the death of a human being could not give rise to a civil action. English courts had already committed themselves to the rule that a claim for personal injury cannot survive the death of the victim. ${ }^{2}$ These two propositions, operating in harness, served to erase all possibility that the bereaved families of tort victims might derive any comfort from the common law. ${ }^{3}$

Possibly this was not a matter of momentous importance at the time of Ellenborough's holding. In those days deliberate homicide accounted for most unnatural deaths, and the culprit was promptly hanged and such lands and goods as he possessed were forfeited to the state. ${ }^{4}$ But changes were to come rapidly. Even before Lord Ellenborough spoke, a young Scotsman had demonstrated the enormous motive power latent in steam. Before the middle of the cen-

- B.A. 1928, University of North Carolina, University of Chicago; J.D. 1931, University of North Carolina; LL.M. 1933, Harvard University. Professor of Law, Louisiana State University.

2 Baker v. Bolton, 1 Camp. 493, 170 Eng. Rep. 1033 (K.B. 1808)

${ }^{2}$ Higgins v. Butcher, Yelv. 89, 80 Eng. Rep. 61 (K.B. 1607); 3 Holdsworth, History OF THE ENGLISH LAw 576 (3d ed. 1927).

${ }^{3}$ For the history of the early common law position in cases of death in England and America, see Malone, The Genesis of Wrongful Death, 17 STAN. L. REv. 1043 (1965). The picture in England is discussed in Smedley, Wrongful Death-Bases of the Common Law Rules, 13 VAND. L. REv. 605 (1960).

"The death penalty continued to be the common punishment for felony (except clergyable offenses) until the 1827 passage of the Administration of Justice in Criminal Cases Act, $7 \& 8$ Geo. 4, c. 28, $\$ \$ 6-7$ (1827). Forfeiture of land and chattels was abolished in 1870 by the Act to Abolish Forfeitures for Treason and Felony, 33 \& 34 Vict., c. 23, \& I (1870). See generally 1 Stephen, History of the Criminal LAw of ENGLAND 457-92 (1883). 
tury, locomotives were drawing heavy trains across the country at what were then perilous speeds. Myriads of people were swarming to the cities where boilers were propelling the machinery of factories. The day of the industrial and transportation accident was at hand, and unnatural death was no longer chiefly the work of the impecunious highwayman or the angry neighbor.

Under these conditions the retention of the older rule was an intolerable prospect. But before judges were afforded a fair opportunity to repent Lord Ellenborough's mistake, the English Parliament moved into action: Lord Campbell's Act (the Fatal Accident Act) came into being in $1846 .^{\circ}$ This was a revolutionary measure that not only repaired previous damage done by the court but also created a new cause of action for death on behalf of widows and children. This new cause of action existed even where the husband or parent would have had none if the injury had been less than fatal. The Fatal Accident Act eventually served as the guide for most American legislatures.

But the story of the evolution of the modern American death statute is not a simple one. The problem of the fatal accident was entirely novel to the lawmakers of the mid-nineteenth century. It involved new conceptions and was fraught with complexities that could not be anticipated. The pressures upon the legislators were in hot competition. The immensity of the tragedy demanded vigorous reform, but the economic needs of the emerging transportation enterprises and of the new industrial society called equally loudly for caution and restraint. The legislative responses were frequently ill-conceived and hastily constructed measures that were destined either to be repealed or to be followed by a patchwork of amendments. Even today many American death statutes bear deforming birthmarks remindful of their origin.

\section{I}

The Earliest Legrslative Efforts

Although the English Parliament failed to face the problem of fatal accidents until the adoption of Lord Campbell's Act in 1846, legislative action of a general character came earlier in several states

The rule in Baker v. Bolton, 1 Camp. 493, 170 Eng. Rep. 1033 (K.B. 1808), was not presented for reconsideration until 1873 in Osborn v. Gillett, L.R. 8 Ex. 88 (1873).

' 9 \& 10 Vict., c. 93, at 531 (1846). 
in America. In Kentucky as early as 1812 several causes of action for personal injuries were made to survive the death of both the victim and the wrongdoer, ${ }^{7}$ and a similar provision was made by the Arkansas legislature in 1838.8 Survival statutes were enacted in Michigan in 1838 and Maine in $1840,^{\circ}$ and while coverage was limited to assault and battery, the lawmakers of that time probably regarded these as being the wrongs most likely to result in death. The Massachusetts legislature, which since 1805 had consistently whittled down the list of tort actions which did not survive at common law, ${ }^{10}$ provided in 1842 for the survival of actions on the case for injuries to the person despite the death of either the victim or the wrongdoer. ${ }^{11}$ Two years later, a similar measure was adopted in Rhode Island, ${ }^{12}$ which, however, like the earlier Maine statute, was restricted to assault and battery.

Although these six survival statutes represent the only instances of efforts by the American legislatures to attack the fatal accident problem in comprehensive terms prior to the English Lord Campbell's Act in 1846,13 they afford no more than a fragmentary picture of the early American legislative scene. Then, as now, the lawmaker's sense of responsibility was most readily aroused when he was pressed by public opinion to remedy some specific misfortune of an impressive character. It is noteworthy in this connection that the first early venture by Parliament with respect to survivorship had come in response to a single dramatic situation: The statute 1 Edward III, enacted in 1327, concerned itself only with the executors of those persons who were slain in the dispute between the Mortimer and

7 Ky. Acts 1811 , ch. 375, §5, at 182 (assault, battery, slander, criminal conversation, and malicious prosecution excluded), also cited in $1 \mathrm{KY}$. Dig. STAT. LAw 88 (Morehead 8: Brown 1834).

${ }^{8}$ ARK. REV. STAT. ch. 4, $\$ 59$ (1838).

- Mich. Rev. Stat. pt. 3, tit. 2, ch. 3, §7 (1838); ME. Rev. Stat. ch. 120, §15 (1840).

10 Mass. Acts \& Laws 1805 , ch. 99, $\$ 2$, at 520 (survival of actions for wrongful acts of law officers); Mass. Laws 1822, ch. 110, $\S 1$, at 187 (survival of actions for replevin and trover); Mass. Laws 1829 , ch. $112, \S l$, at 182 (survival of actions for injury to realty); and Mass. Laws 1834 , ch. 2, at 4 .

11 Mass. Acts \& Resolves $1841-42$, ch. 89, $\S 1$, at 539 (1842).

12 R.I. Pub. Laws $\$ 25$, at 132 (1844). This statute also provided for survival of miscellaneous other actions.

${ }^{18}$ Survival provisions in Vermont, Vt. Laws 1847 , No. $42, \S 2$, at 29 , and in Connecticut, Conn. Acts 1848 , ch. 5, $\$ 2$; at 7 , also cited in CoNN. REv. STAT. 1849, ch. 6, $\$ 83$, at 72 , providing for survival of all personal injury claims, barely failed to qualify for this group of measures preceding Lord Campbell's Act. However, they antedate any general wrongful death measure in these states. 
Despenser factions ${ }^{14}$-a historic struggle that resulted in the deposition of Edward II. Similarly, much of the first American legislation on death arose as a direct reaction to some vivid need which had captured the attention of the lawmakers. As early as 1647, for example, the colonial legislature of the Massachusetts Bay Colony took notice of "the great peril which men, horses, teams, and other cattle are exposed to by reason of defective bridges and highways between Boston and Salem and elsewhere in this jurisdiction." The lawmakers imposed a fine of one hundred pounds upon the persons or the public body chargeable with the maintenance of any road or bridge whose defective condition resulted in the death of a highway user. The penalty, which was enforced by way of presentment, was for the benefit of the parents, wife, and children of the deceased.15 This measure was continued in substantially the same form by state statute in $1786^{16}$ and it has persisted with modifications in Massachusetts law ever since. ${ }^{17}$

The example of the Bay Colony was followed by a similar penal highway death provision in Connecticut in $1673^{18}$ and in New Hampshire in 1719.19 Although the New Hampshire measure was repealed shortly after the Revolution, ${ }^{20}$ the Connecticut statute remained on the books until 1848. ${ }^{21}$ When Maine broke away as a separate state from Massachusetts in 1820, it adopted a penal provision modeled after that of the parent Commonwealth, ${ }^{22}$ and this act, with some modification, still appears in the Maine statutes. ${ }^{23}$

141 Edw. 3, stat. 1, c. 3 (1327), providing in substance that the executors of persons slain in this struggle should have an action with respect to the goods and chattels of their testator. Three years later the benefits of this provision were extended to all executors. 4 Edw. 3, c. 7 (1330).

${ }^{15}$ Mass. Bay Charter \& Gen. Laws 1814, ch. 23, §4, at 269 (1693).

${ }^{16}$ Mass. Acts \& Laws 1786-87, ch. 81, at 250 (1787), also cited in 1 Laws of Mass. 1780-1807, at 386 (1807).

${ }^{17}$ Mass. Acts \& Resolves 1949, ch. 427, $\S 1$, at 365, as amended, MAss. ANN. LAws ch. 229, § 1 (Supp. 1964).

${ }^{18}$ Laws of Conn. 1673, at 7 (Brinley 1865). After the Revolution the substance of the colonial measure was re-enacted in 1 Conn. Pub. Stat. Laws 1808, tit. 29, $\$ 3$, at 120.

${ }^{10}$ N.H. Acts \& Laws 1606-1725, at 151, also cited in 2 N.H. Laws 332 (Batchellor 1913).

${ }^{20}$ Perpetual Laws of N.H. 1776-1789, at 60 (Melcher 1789), also cited in 5 N.H. Laws 122 (Metcalf 1916).

${ }_{21}$ Conn. Pub. Acts 1848, ch. 49, at 43.

222 Me. Laws, ch. 118, $\$ 17$, at 618 (1821). The penalty was originally set at $\$ 300$, but when the provision reappeared in ME. REv. STAT. ch. 25, $\$ 89$ (1840), it provided for a maximum of $\$ 1,000$.

${ }^{2 a}$ Me. Laws 1953, ch. 344, $\$ 88$, at 355 , as amended, ME. Rev. StAT. ANN. ch. 96, $\$ 89$ (Supp. 1963). 
In pioneer communities of the South and West the threat of the private duel exerted a very appreciable influence on tort law. ${ }^{24}$ The disturbing prevalence of this genteel brand of slaughter prompted the legislature of Kentucky in 1839 to authorize a suit in trespass by the widow and children of any person killed in a duel. Provision was made for the recovery of vindictive damages against the assailant and all other participants. ${ }^{25}$ This statute remained in the law until 1942.26

Although the Kentucky anti-dueling act was the only measure of its kind prior to the date of Lord Campbell's Act, death by assault and violence continued to attract legislative attention thereafter. In 1855, only one year after the adoption of its first general death statute, the Kentucky legislature made special provision for the widow or heirs of any person killed"7 through the use of "the weapons popularly known as colts, brass knuckles, slungshots, or any imitation or substitute therefor."28 This measure authorized the recovery of "such damages as a jury may deem right," including a provision for imprisonment in the event of failure to satisfy the judgment. ${ }^{29}$ A modified version of this act is still in effect in Kentucky. ${ }^{30}$

As early as 1854 a dueling statute similar to the Kentucky measure was passed by the legislature of Washington. ${ }^{31}$ This enactment was the first to deal with fatal accidents in that state, and it preceded the Washington general death statute ${ }^{32}$ by fifteen years. The Washington dueling measure continued in force until 1917.33

\footnotetext{
34 In an effort to subordinate the desire for personal vengeance aroused by insults, the legislatures of several southern states enacted anti-dueling statutes that authorized an award of damages for insulting language calculated to lead to a breach of the peace. See the discussion in Malone, Insult in Retaliation, 11 Miss. L.J. 333 (1939). ${ }^{25} \mathrm{Ky}$. Acts 1838-39, ch. 1214, at 166 (1839), also cited in Ky. DiG. Stat. LAws 572 (Loughborough 1842).

${ }^{20}$ The duelling measure was omitted when the Kentucky general death statute was revised in that year. KY. REv. STAT. $\$ \$ 411.130-150$ (1942).

${ }_{27}$ I Ky. Acts 1855 , ch. 636, $\$ 3$, at 97 (1856).

${ }^{28} 1 \mathrm{Ky}$. Acts 1855 , ch. 636, $\$ 1$, at 96 (1856).

${ }^{20} 1 \mathrm{Ky}$. Acts 1855 , ch. 636, $\$ 3$, at 97 (1856).

${ }^{20} \mathrm{Ky}$. Rev. Stat. ANN. $\$ 411.150$ (1963).

In 1866 the statute was held unconstitutional for a defect in its title. O'Donoghue v. Akin, $63 \mathrm{Ky} .478$ (1866). However, a substitute measure was enacted the same year authorizing an award, including vindictive damages, to the widow and children for death resulting from the careless, wanton, or malicious use of firearms or other deadly weapons. Ky. Acts 1865-66, ch. 85, at " 6 (1865). This act has never been repealed. s1 Wash. Terr. Stat. $1854, \S 496$, at 220 .

se Wash. Terr. Stat. 1869, ch. 58, §658, at 165 .

sa Wash. Laws 1917 , ch. $123, \S 4$, at 495 .
} 
The Railway Death Statutes

By the middle of the nineteenth century we find legislative attention suddenly arrested by the effusion of human tragedy brought about by the emergence and rapid growth of the steam railway. As we shall see, the influence of the transportation age on death legislation was enormous. Injuries and deaths suddenly multiplied at an alarming pace. ${ }^{34}$ The legislatures moved into action in this single field with surprising promptness and often with but little notion of what legal theory, if any, would be appropriate to meet the needs of bereaved families clamoring for assistance. From 1840 until 1887 sixteen states made special provision for death resulting from railroad operations. Sometimes the railroads were singled out specifically for legislative treatment, while at other times they were included along with other public carriers, such as steamboats, ferries and even stage coaches. Some of the measures awarded punitive damages while others conferred a separate civil cause of action for the benefit of the families. Some proceeded on a survival basis while others merely authorized "a suit" by the personal representative with spare direction as to the disposition of the proceeds of the judgment.

The prevalence of railroad statutes perhaps is attributable to the bewildering novelty of the entire problem of corporate responsibility for the negligence of agents and servants. What are now commonlyaccepted notions of respondeat superior were just then emerging as a product of transportation and industrial accidents. The liability of an employer for anything beyond those acts of employees which the employer had personally directed was poorly understood. ${ }^{35}$ The modern conception of "scope of employment" was just then taking shape, ${ }^{36}$ and was hemmed in by developing restrictive doctrines

si The illustrated newspapers in this period were continuously filled with illustrations and editorials on railroad accidents. "Accident broadsides" printed in lurid colors found ready sale. See the interesting account in Dunbar, A History of Travel IN AMERICA 1056-61 (new ed. 1937). Contemporary cartoons in scathing denunciation of the indifference of railroad operators will be found in this volume at 1066, 1069, 1073. See also Silcox, SAFETY in EArLy AMERICAN RAILIway Operations: 1853-1871 (1956).

${ }^{35}$ It was not until 1842 (only a decade prior to the period we are discussing) that the English Court of Common Pleas made its first announcement that a corporation could be held liable in trespass. Maund v. Monmouthshire Canal Co., 4 Man. \&: G. 452, 134 Eng. Rep. 186 (C.P. 1842). See the excellent discussion in BATY, Vicarious LIABILITY 65" (1916).

${ }^{30}$ See Seavey, Speculations as to "Respondeat Superior," in HARVARD LEgal Esshys 433, 453 (1934), also in StUdies IN AGENCY 129, 155 (1949). 
such as the fellow servant rule, which was capturing the judicial fancy during this period. Problems of corporate responsibility were virtually synonymous with problems of railroad liability, and it is little wonder that the early legislatures should believe express provision for railroad liability was necessary.

The whole story of railroad death legislation is a complex one. We will begin with the four states whose legislators attacked railroad or carrier deaths before they made any effort to come forward with a general death statute, and thereafter will turn to those states which simultaneously provided a railroad death and general death measure.

\section{A. Massachusetts}

The first of the railroad death acts was the Massachusetts penal measure of 1840. It afforded protection only for the families of railroad passengers who were killed through the negligence of the proprietors or the gross negligence of railroad employees. ${ }^{37}$ However, through a process of accretion extending over nearly a half century, the Massachusetts legislature expanded the benefit of death protection against railroads to all victims who were not employees of the carriers, ${ }^{38}$ and finally, in 1883 , even to those workers. ${ }^{39}$ Street railways were included as defendants in $1864,{ }^{40}$ and by 1897 electric and power companies had been brought within the fold.4t This legislative proliferation finally led to a comprehensive death measure in 1898.42 But the initial Massachusetts scheme of directing penal measures against specific dangerous enterprises has left its indelible imprint upon the death law of that commonwealth. Even after the comprehensive death provision of 1898 was enacted, the specific provisions against carriers and public utilities continued to clutter the statutes until a general legislative overhauling took place in 1958.43 The highway death measure previously referred to ${ }^{44}$ still remains on the books, and special restrictive provisions relating

\footnotetext{
${ }^{87}$ Mass. Acts \& Resolves 1840 , ch. 80, at 224.

${ }^{88}$ Mass. Acts \& Resolves 1853, ch. 414, at 622 . See also Mass. Acts \& Resolves 1871, ch. 352 , at 699 (death at crossings through failure to give statutory crossing signal).

${ }^{30}$ Mass. Acts \& Resolves 1883, ch. 243, at 532.

${ }^{10}$ Mass. Acts \& Resolves 1864, ch. 229, $\S \S 37-38$, at 166.

${ }^{41}$ Mass. Acts \& Resolves 1897, ch. 416, at 388.

\& Mass. Acts \& Resolves 1898, ch. 565, at 724.

${ }^{43}$ Mass. Acts \& Resolves 1958, ch. 238, at 122, MAss. GEN. LAws ANN. ch. 229, $\$ 2$ (Supp. 1964).

"See text accompanying notes $15-17$ supra.
} 
exclusively to railroad deaths will be found even in the most recent statutes. ${ }^{45}$

More importantly, the original penal attack persists today in full force in Massachusetts and must be taken into consideration in any effort to understand the administration of the death provisions of that state. Up until 1881 the penalty was imposed through a criminal proceeding instituted by indictment in the name of the commonwealth. ${ }^{46}$ Even thereafter, when a civil remedy was given in addition to the criminal proceeding, ${ }^{47}$ it remained necessary to establish that the death of the victim was due to the gross negligence of the defendant's servants whenever the claimant attempted to resort to respondeat superior. ${ }^{48}$ The latter limitation was not removed until $1907 ;^{40}$ and even today the statutes expressly require that damages be assessed with reference to the degree of culpability of the defendant or its servants or agents. ${ }^{50}$ In short, the spirit of the earliest measure adopted by the colonial legislature in 1647 has exerted its influence upon the Massachusetts law of today.

\section{B. Maine}

Although, as we have seen, ${ }^{51}$ the legislatures of Maine and Arkansas had made prior provision for the survival of personal injury claims, these measures received little attention in the earliest cases. In 1848 the Maine legislature enacted a penal provision directed specifically at the captain or person having charge of a steamboat or locomotive whose operation resulted in the death of a passenger through a boiler explosion. ${ }^{52}$ The general tenor of this act suggests that it was probably directed against the then prevalent practice of railroad and steamboat racing. Seven years thereafter a broader statute imposed a fine of not less than 500 nor more than 5000 dollars for the benefit of the families of all persons except railroad employees who, while in the exercise of reasonable care, were killed through the gross negligence of a servant of the railroad. ${ }^{53}$ Two

\footnotetext{
${ }^{45}$ Mass. Gen. Laws ANN. ch. 229, \$2 (Supp. 1964).

${ }^{4}$ Mass. Acts \& Resolves 1881, ch. 199, § 3, at 522 .

${ }^{47}$ Mass. Acts \& Resolves 1886, ch. 140, at 117.

${ }^{48}$ See, e.g., Hicks v. New York, N.H. \& H.R.R., 164 Mass. 424, 41 N.E. 721 (1895).

${ }^{10}$ Mass. Acts \& Resolves 1907, ch. 375, $\S 1$, at 324; Mass. Acts \& Resolves 1907, ch. $392, \S 1$, at 338 .

so Mass. Gen. Laws ANn. ch. 229, $\$ 2$ (Supp. 1964).

${ }^{81}$ See notes 8.9 supra and accompanying text.

${ }^{82}$ Me. Acts \& Resolves 1848, ch. 70, §2, at 59.

${ }^{58} \mathrm{Me}$. Acts \& Resolves 1855, ch. 161, §1, at 159.
} 
years later the requirement that the negligence be gross was omitted. ${ }^{14}$ The substance of these measures remained on the statutes until the enactment of a general death provision in $1891 .^{55}$

\section{Arkansas}

The first groping of the Arkansas legislature toward a death provision took the form of an ineptly-worded 1874 statute directed at railroad deaths. ${ }^{56}$ This measure, unlike the statutes of Massachusetts and Maine, was not penal in character nor was it restricted to death occasioned by the gross neglect of railroad employees. Although it is difficult to gather the meaning of the Arkansas legislature from the language of this measure, the supreme court of the state proceeded by analogy to statutes in other jurisdictions modeled after Lord Campbell's Act, and held that it authorized an award of damages to a mother for loss of services arising from the death of her child. ${ }^{57}$ Eight years later, after the enactment of Arkansas' first general death statute, ${ }^{58}$ the court of that state held that this latter measure impliedly repealed the earlier railroad act. ${ }^{59}$

\section{New Hampshire}

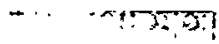

The final instance in which a special railroad statute preceded any death measure of a general character occurred in New Hampshire. The legislature of that state in 1850, following the general

¿ ME. REv. STAT. ch. 51, \$42 (1857).

8s Me. Acts \& Resolves 1891, ch. 124, $\$ 1-2$, at 135 .

so "When any adult person be killed by railroad trains running in this State, the husband may sue for damages to a wife. In all other cases the legal representative shall sue. ... When the person killed or wounded be a minor, the father, if living, if not, then the mother, if neither be living, then the guardian may sue for and recover such damages as the court or jury trying the case may assess." Ark. Acts 1874 , $\$ 3$, at 133.

${ }^{57}$ Little Rock \& Ft. S. Ry. v. Barker, 33 Ark. 350 (1878). The court denied tbat the cause of action was one that survived from the child to the mother, and hence rejected the defendant's argument that there could be no recovery under the measure for instantaneous death. Id. at 361. But it allowed damages for medical expenses, which usually are allowed under survival statutes. Id. at 360, 362 .

${ }^{88}$ Ark. Acts 1883, No. 53, at 75.

${ }^{80}$ Davis v. St. Louis, I.Mt. \& So. Ry., 53 Ark. 117, 124, 13 S.W. 801, 802 (1890). The court, conceding that there was no express repeal of the earlier special act, refused to admit the prospect of different legal consequences flowing from death, dependent upon the fact that the killing was by a railroad. As will be indicated subsequently, this approach to a conflict between general and special death statutes has not generally prevailed.

Despite the holding in Davis v. St. Louis, I.M. \& S. Ry., supra, the railroad provision persisted in its original form through several revisions of the death statute. Finally in 1961 all death references were stricken from the statute. ARK. STAT. ANN. \$73-1003 (Supp. 1963). 
Massachusetts pattern, enacted a penal measure imposing a fine for death through railroad operations. ${ }^{60}$ This was repealed twenty-nine years later when the legislature enacted a general death act ${ }^{61}$ which led ultimately to the passage of New Hampshire's survival statute, the prevailing measure for death today in that state. ${ }^{62}$

\section{III}

\section{The Dual Coverage Death Acts}

The states discussed above, which initiated their attack on the fatal accident problem by singling out railroad deaths for exclusive treatment, gradually gave up this approach and adopted general statutes of one type or another. As a result, the courts in these jurisdictions were spared the embarrassing difficulty involved in dealing with overlapping and frequently conflicting statutory remedies for deaths. This, however, was not to be true in ten other jurisdictions whose legislatures attempted to remedy deaths occasioned by railroad operations and those resulting from all other tortious conduct through separate and distinct provisions in a single, combination-type measure. Such was the initial situation in Kentucky, Rhode Island, North Carolina, Missouri, Colorado, New Mexico, Texas, Arizona, and both Dakotas. In most of these states the facts necessary to establish a cause of action for death resulting from the operation of a railroad differed in one or more important respects from the showing required by the same statute to recover for fatal injuries caused by other defendants. Often the beneficiaries designated by the railroad death provision were different from those who were entitled to recover under the general death section. Frequently the entire theory of recovery as well as the scheme for assessing damages depended solely upon the fortuitous circumstance

${ }^{\circ 0}$ N.H. Laws 1850 , ch. 958, $\$ 7$, at 928 . This original statute unlike the Massachu. setts measure, included death occasioned by the "gross negligence or by the carelessness of [railroad] ... servants or agents ..." (Emphasis added.) The Massachusetts statute provided only for "the unfitness or gross negligence or carelessness of [railroad] . . . servants or agents ...." Mass. Acts \& Resolves 1840, ch. 80, at 224. This slight but significant change in phraseology in a statute which otherwise slavishly tracks the Massachusetts act clearly indicates a legislative intention to cover death by ordinary as well as gross negligence on the part of railroad employees. When, however, this measure was incorporated into N.H. GEN. STAT. 1867, ch. 264, § 14, the phraseology of the Massachusetts statute was substituted.

${ }^{61}$ N.H. Laws 1879 , ch. 35 , at 358.

-2 N.H. Laws 1887, ch. 71, at 454, as amended, N.H. REv. STAT. ANN. \$§556:11. 556:14 (1955), as amended, N.H. REv. STAT. ANN. §556:13 (Supp. 1963). 
that the death was caused by a railroad rather than some other wrongdoer.

We can only surmise as to why a legislature would deliberately adopt a dual treatment of this kind, and conjecture is made all the more difficult by the marked dissimilarities prevailing among the various statutes in this group.

One possible explanation stems from the observation that the state legislatures of this period, deprived of any common law principle to assist them in developing a remedy for wrongful death, might be expected to seek out a precedent from the statutes of other jurisdictions. At the inception of the movement toward dual coverage in 1853, the legislatures of the two most influential statesMassachusetts and New York-had already approached the death problem in contradictory fashion. The Massachusetts lawmakers of 1840 had adopted a penal attack restricted to railroad deaths, ${ }^{63}$ while in New York the legislature in 1847 had faithfully followed the comprehensive model of England's Lord Campbell's Act. ${ }^{64}$ The sudden urgency of the problem of accidental death caused the legislatures of the remaining states to be faced with a choice between two opposed theories, both of which were virtually untried. It is not surprising that debates in the legislative halls would lead in some instances to the ill-advised but cautious conclusion that both attacks should be adopted in combination.

The attractiveness of an approach that would include a specific attack upon death resulting from the negligence of railroad employees was probably enhanced by the bewildering problem of respondeat superior, discussed above. 65 The legislature of Massachusetts had expressly restricted railroad liability for death to instances where the servants or agents were chargeable with gross neglect or where they were selected with knowledge of their unfitness. ${ }^{66}$ It was entirely predictable that several states would follow the Massachusetts example.

Above all, there must be taken into account the sharply conflicting polices that competed in influencing the legislators of that

\footnotetext{
${ }^{\circ 8}$ Mass. Acts \& Resolves 1840, ch. 80, at 224; see text accompanying notes 37-50 supra.

o4 2 N.Y. Laws 1847 , ch. 450 , at 575 .

¿5 See text accompanying notes 35-36 supra. text.

00 Mass. Acts \& Resolves 1840, ch. 80, at 224; see note 37 supra and accompanying
} 
period. The sorry spectacle of mass slaughter on the rails impelled the lawmakers toward drastic action, while the recognized need to encourage transportation activity without prohibitive cost strongly suggested caution and restraint in dealing with railroad accidents. It is hardly a matter for surprise that in some instances the railroads were given preferential treatment, while in other respects they fell under a harsher hand than other defendants.

\section{A. Kentucky}

When the legislature of Kentucky adopted its fatal accident act in 1854, the state's statute compensating the widows of the victims of duelling ${ }^{67}$ had already been in effect for fifteen years. Hence, the device of according legislative recognition to deaths occasioned by specific activities was not unfamiliar in that state. The first section of the 1854 measure provided in substance that if the life of any person other than a railroad employee were lost through the negligence or carelessness of either the managers of a railroad or of their servants or agents, the personal representative of the deceased could institute suit and recover damages "in the same manner that the person himself might have done for any injury where death did not ensue." 88 Although it is unclear whether this was intended as a survival measure or as a recognition of an independent right in the administrator to recover for the death, certainly the provision had none of the characteristics of a penal measure.

However, the third section of the same statute, dealing with all other wrongful deaths, betrayed an entirely different approach:

[I]f the life of any person or persons is lost or destroyed by the willful neglect of another person or persons [or corporations] ... their agents or servants, then the personal representative of the deceased shall have the right to sue such person ... and to recover punitive damages for the loss or destruction of the life aforesaid. (Emphasis added.) ${ }^{69}$

Under these two measures, with their separate spheres of operation, the identity of the defendant determined whether the damages were regarded as penal (i.e., measured by the culpability of the

${ }^{87} \mathrm{Ky}$. Acts 1839, ch. 1214, at 166, also cited in KY. Dic. Stat. Laws tit. 108, $\$$ I (Loughborough 1842); see text accompanying notes 24-26 supra.

${ }^{68}$ Act to Redress Injuries Arising from the Neglect or Misconduct of Railroad Com. panies, and Others, $1 \mathrm{Ky}$. Acts 1853-54, ch. 964, $\$ 1$, at 175 (1854).

${ }^{60} \mathrm{I} \mathrm{Ky}$. Acts 1853-54, ch. 964, §3, at 175 (1854). 
fatal act) or as compensatory. ${ }^{70}$ Damages were awarded for ordinary negligence whenever the suit was against a railroad, while no claim for death could be recognized against any other wrongdoer in the absence of a showing of willful neglect. Moreover, the Kentucky courts adopted the position that gross negligence could not be regarded as the equivalent of willful neglect under section $3 .{ }^{11} \mathrm{~A}$ high tide of strict construction was reached when the Kentucky Supreme Court denied a personal representative any right under this section for a death caused by an intentional assault, since the deliberate aggression by the defendant amounted to something more than willful neglect. ${ }^{72}$

The situation became more complex when the legislature of Kentucky in 1873 made a seemingly trivial change in the general death provision (section 3). In addition to the personal representative (who formerly was the only person entitled to sue under that section), the widow or heirs were authorized to bring suit. ${ }^{73}$ No corresponding change was made, however, in the provision for railroad deaths (section 1), and the cause of action here continued to be vested solely in the personal representative. Following this change the Kentucky Supreme Court gave an interpretation to the amended section 3 that abetted the inconsistency. ${ }^{74}$ The 1873 amendment, said the court, served to restrict the right to maintain

\footnotetext{
${ }^{70}$ The constitutionality of $\$ 3$ was sustained against an argument that its penal character exposed the defendant to double punishment. Chiles v. Drake, $59 \mathrm{Ky}$. (2 Met.) 146, 149.53 (1859). However, despite the fact that willful neglect must be shown under $\S 3$, it was held erroneous to instruct the jury that it must return punitive damages if willful neglect was found. Louisville \& N.R.R. v. Brooks' Adm'x, $83 \mathrm{Ky}$. $129,138-41$ (1885).

${ }^{71}$ Hansford's Adm'x v. Payne \& Co., $74 \mathrm{Ky}$. (11 Bush) 380 (1875); Jacobs' Adm'r v. Louisville \& N.R.R., 73 Ky. (10 Bush) 263 (1874); Louisville \& N.R.R. v. Filbern's Adm'x, $69 \mathrm{Ky}$. (6 Bush) 574 (1869) (willful neglect must involve either "intentional wrong or such reckless disregard of security and right as to imply bad faith").

${ }^{72}$ Spring's Adm'r v. Glenn, $75 \mathrm{Ky}$. (12 Bush) 172 (1876). In partial justification of this decision, it should be noted that decedent's wife could resort to the special Kentucky statute authorizing a widow or heir to maintain suit for the death of a husband who was killed through the malicious use of "fire-arms, or other deadly weapons." Ky. Acts 1865-66, ch. 85, $\S 1$, at 6 (1866) (replacing 1 Ky. Acts 1855, ch. 636, at 96). If no such weapon were used, however, there was apparently no remedy for intentional killing.

Cf. Chiles v. Drake, $59 \mathrm{Ky}$. (2 Met.) 146, 149-50 (1859) (defendant aimed a gun at $A$ and killed B; suit properly instituted under $\S 3$ of the death act for willful neglect, rather than under the special firearm statute then prevailing).

${ }^{73}$ KY. Gen. STAT. ch. 57, \$ 3 (1873).

7 Henderson's Adm'r v. Kentucky Cent. R.R., 86 Ky. 389, 5 S.W. 875 (1887); accord, Jordan's Adm'r v. Cincinnati, N.O. \& Tex. Pac. R.R., 89 Ky. 40, 11 S.W. 1013 (1889).
} 
suit under that section to the widow and children. ${ }^{75}$ While the personal representative retained the right to sue under the amended statute, the court restricted that right to authority to sue only on behalf of the widow and children. ${ }^{78}$ It supported its conclusion with the observation that the term "heirs" should be interpreted to mean only children. ${ }^{77}$

Therefore, unless there were a widow and/or children, no suit under section 3 could be maintained. As a result, parents were - denied all right to recover for the wrongful death of their children, and a husband could not maintain an action for the death of his wife. $^{78}$ If by chance, however, the defendant happened to be a railroad, the personal representative could proceed for damages under section 1 without reference to the existence of any particular beneficiary. ${ }^{79}$

Further restrictive interpretations by the court were to follow. The right to proceed exclusively under the railroad provision was limited to instances where the wrongdoing amounted to something less than willful neglect. ${ }^{80}$ Recall that damages under this section were wholly compensatory in character, even if the representative were in a position to establish gross negligence on the part of the railroad or its employees. If the representative should attempt to secure an award of punitive damages by alleging that the railroad was guilty of willful neglect, he would find that his claim had become qualified exclusively under the general death provision, and his suit was subject to dismissal unless the existence of a widow or children could be established. ${ }^{81}$

The artificialities of the Kentucky statute and the effect of the inconsistencies between its two provisions were heightened by the

\footnotetext{
${ }^{75} 86 \mathrm{Ky}$. at $394-95,5$ S.W. at 877.

${ }^{78} 86 \mathrm{Ky}$. at 395,5 S.W. at 877.

"I Ibid.

${ }^{78}$ Lexington City Ry. v. Kayse, 10 Ky. L. Rep. 321 (Super. Ct. 1888); Kentucky Cent. R.R. v. McGuinty, 9 Ky. L. Rep. 860 (Super. Ct. 1888).

${ }^{70}$ Owensboro \& N. Ry. v. Barclay's Adm'r, 102 Ky. 16, 43 S.W. 177 (1897); Givens v. Kentucky Cent. Ry., 89 Ky. 231, 12 S.W. 257 (1889); cf. Louisville \& N.R.R. v. McElwain, 98 Ky. 700, 34 S.W. 236 (1896); Louisville \& N.R.R. v. Morris, 14 Ky. L. Rep. 466, 20 S.W. 539 (Ct. App. 1892).

${ }^{80}$ Cincinnati, N.O. \& Tex. Pac. Ry. v. Prewitt's Adm'r, 92 Ky. 223, 17 S.W. 484 (1891); Givens v. Kentucky Cent. Ry., 89 Ky. 231, 233-34, 12 S.W. 257, 258 (1889).

${ }^{81}$ Cincinnati, N.O. \& Tex. Pac. Ry. v. Prewitt's Adm'r, 92 Ky. 223, 17 S.W. 484 (1891); Baker's Adm'r v. Louisville \& N.R.R., 18 Ky. L. Rep. 465, 17 S.W. 191 (C.. App. 1891).
} 
court's persistent refusal to recognize its earlier survival statute 82 in any case in which damages under either section of the death act presently under discussion were sought. The claimant was forced to elect whether to proceed under the survival statute or under the applicable death act. ${ }^{83}$ Even the common law right of the husband to recover for the loss of his wife's services from the time of injury until her death, which has seldom been questioned elsewhere, was denied by the courts of Kentucky whenever the facts showed that a suit could be maintained under the new death statute. ${ }^{84}$ This unhappy state of affairs under the dual coverage provisions continued until the people of the state in 1891 approved an amendment to the Kentucky Constitution providing a single death measure modeled after the familiar Lord Campbell's Act. ${ }^{85}$

\section{B. Rhode Island}

In 1853, one year earlier than the date of enactment of the Kentucky measure, the Rhode Island legislature adopted a single statute that similarly attempted to deal separately with carrierinflicted deaths and deaths caused by the misconduct of other de-

82 Ky. Acts 1811 , ch. 375, $\$ 5$, at 182 (1812), also cited in I KY. Dig. Stat. LAw 88 (Morehead \& Brown 1834); see note 7 supra and accompanying text. The Kentucky provision of 1812 was the earliest legislative measure in the Anglo-American world to recognize the survival of personal injury claims. The statute, however, received little judicial interpretation until after the effective date of the death statute. In 1872 the court construed the survival provision in a manner which deprived it of all significance in cases where the accident was fatal, by observing, "the common law conferred no right of action for an injury resulting in the loss of life, and the statute referred to, being merely declaratory of the common law, gives no right of action to the personal representative when the intestate himself had none." Louisville \& Portland Canal Co. v. Murphy, 72 Ky. (9 Bush) 522, 534 (1872); see Louisville, C. \& L.R.R. v. Case's Adm'r, $72 \mathrm{Ky}$. (9 Bush) 728 (1873). Two years later, however, the court repiudiated this interpretation and recognized that the statute allowed survival for fatal injuries except where death was instantaneous. Hansford's Adm'x v. Payne \& Co., $74 \mathrm{Ky.} \mathrm{(11} \mathrm{Bush)} 380$ (1875).

sonner's Adm'x v. Paul, 75 Ky. (12 Bush) 144 (1876). In Hackett v. Louisville, St. L. \& Tex. Pac. Ry., 95 Ky. 236, 24 S.W. 871 (1894), a father, suing as administrator under the death act, included a count in the alternative for pain and suffering between time of accident and death. The court held that even though the parent had no standing to sue under the death act because of the absence of widow or child, his effort to recover under the act constituted an election that deprived him of all right to sue on a survivorship theory thereafter. See Evans, Death by Wrongful ActSurvivorship of Tort Actions in Kentucky, 21 KY. L.J. 369, 382-83 (1933).

${ }^{84}$ Louisville \& N.R.R. v. McElwain, 98 Ky. 700, 34 S.W. 236 (1896).

as $\mathrm{KY}$. Const. $\$ 241$. The debates of the constitutional convention betray the public dissatisfaction with the Kentucky decisions which restricted recovery under the 1873 amendment to the general death provision to instances where there was a surviving wife or child. 4 Kentucky Constitutional. Debates $4715-20$ (1890). The constitutional provision was implemented by Ky. Acts 1893, ch. 252, $\$ 3-6,10$, at 1383 . 
fendants. ${ }^{86}$ As originally enacted, section 1 , the provision directed against carriers, covered only the deaths of passengers and persons in the care of the defendant. In 1855, however, families of highway users $^{87}$ killed through the operation of trains were included..$^{88}$ Furthermore, the original carrier enactment provided that unless the death was attributable to the personal default of the proprietors themselves, it had to be shown that the fatality was caused by the gross negligence or carelessness of railroad agents and servants, ${ }^{80}$ but the 1855 amendment also eliminated this requirement. ${ }^{.0}$

Again, however, as in Kentucky, a different scheme was established where the death was attributable to a defendant other than a carrier. Section 6 of the original enactment authorized a suit "in all cases where the death of any person ensues from injury inflicted by the wrongful act of another ...." (E1 (Emphasis added.) The Rhode Island Supreme Court noted the difference in phraseology between this section and the carrier section. Accordingly, it denied recovery to the parents of a child who was killed when it fell into a cistern that had been left uncovered through the carelessness of the defendant; the death, said the court, was due merely to a wrongful omission.92 The opinion observed that the term "wrongful act" in the general section might appropriately be interpreted as including any negligent misconduct if it were not for the fact that in the railroad section the words "negligence or carelessness" appeared without qualification. ${ }^{3}$ This distinction between act and omission persisted in the Rhode Island decisions whenever the death claim was against some defendant other than a carrier. ${ }^{94}$

In several respects the Rhode Island statute marked an advance over the Kentucky measure. A single theory of wrongful death

\footnotetext{
${ }^{86}$ R.I. Acts \& Resolves 1853, Oct. Sess., §§ 1-6, at 257.

87 "Highway" was interpreted to include navigable waters so the act would include the occupant of a sailboat who was killed through the negligent operation of a steam. boat on open waters. Chase v. American Steamboat Co., 10 R.I. 79 (1871), aff'd on other grounds, 83 U.S. (16 Wall.) 522 (1872).

${ }^{88}$ R.I. Acts \& Resolves 1855, Jan. Sess., §8, at 15, also cited in R.I. REv. Stat. ch. $176, \S 16$ (1857).

${ }^{89}$ R.I. Acts \& Resolves 1853, Oct. Sess., \$ 1, at 257.

${ }^{\circ 0}$ R.I. Acts \& Resolves 1855, Jan. Sess., $\$ 8$, at 15, also cited in R.I. Rev. STAT. ch. $176, \S 16$ (1857).

${ }^{91}$ R.I. Acts \& Resolves 1853, Oct. Sess., §6, at 258.

${ }^{92}$ Bradbury v. Furlong, 13 R.I. 15 (1880).

${ }^{93}$ Id. at 16-17.

os Myette v. Gross, 18 R.I. 729, 30 Atl. 602 (1894) (decedent killed due to employer's neglect to shore up roof of mines).
} 
prevailed under both sections and the beneficiaries were the same persons irrespective of whether the suit was against a carrier or some other wrongdoer. However, with respect to survivorship, the Rhode Island courts adopted a position even more conservative than that of Kentucky. The legislature in 1855 had provided unequivocally for the survival of all personal injury claims. ${ }^{95}$ In Kentucky, a plaintiff was allowed to elect whether to proceed under the death or survival statute where both might apply. ${ }^{98}$ The Supreme Court of Rhode Island, however, relying largely upon English decisions that dealt solely with survival at common law, held that the survival statute applied only to non-fatal injuries where the victim died from some extraneous cause. ${ }^{97}$ In consequence, all death claims fell within the exclusive domain of the death statute with its dual coverage. This latter measure was ultimately repealed by the Judiciary Act of 1893 and a single comprehensive statute based upon Lord Campbell's Act was substituted therefor. ${ }^{98}$

\section{North Carolina}

There is a striking similarity between the Rhode Island statute of 1853 and North Carolina's first death act, adopted in 1854.99 Under both measures the railroad defendant was made liable for death resulting from either the acts or omissions of the proprietor or his servants, while other defendants were responsible only for the fatal consequences of affirmative acts. In the case of Rhode Island one might suspect at first that this distinction was the result of indifferent draftsmanship. But an examination of the language

OE R.I. REV. STAT. ch. 176, $\$ 10$ (1857). Under this provision causes of action in both trespass and trespass on the case survived, indicating an intention to provide for survival of omissions as well as of acts.

This same bill also amended the death act. See notes 88 and 90 supra and accompanying text.

Rhode Island had previously provided for survival of claims for assault and battery. See note 12 supra and accompanying text.

oc See text accompanying notes 82-84 supra.

${ }^{07}$ Lubrano v. Atlantic Mills, 19 R.I. 129, 32 Atl. 205 (1895). This position has been adopted in two other jurisdictions, Illinois and Kansas. Holton v. Daly, 106 Ill. 131, 136 (1882); McCarthy v. Chicago, R.I. \& Pac. R.R., 18 Kan. 46, 52 (1877). The same view prevailed for a short time in Kentucky, Hansford's Adm'x v. Payne \& Co., $74 \mathrm{Ky}$. (11 Bush) 380 (1875), but was later rejected in favor of an election theory, Hackett v. Louisville, St. L. \& Tex. Pac. Ry., 95 Ky. 236, 24 S.W. 871 (1894).

${ }^{\circ 8}$ R.I. Judiciary Act of 1893 , ch. 13, $\$ 14$, at 71 , also cited in R.I. GEN. LAws 1896, ch. 233, § 14 .

${ }^{\circ 0}$ N.C. Pub. Laws 1854-55, ch. 39, $\$ \S 1-4$, at 97, also cited in N.C. Rev. Code ch. 1, §§ 8-11 (1854). 
of the North Carolina statute (which, in general terms, tracks Lord Campbell's Act in both its provisions) can leave no doubt that the difference between the two sections was deliberate. ${ }^{100}$ The seemingly unaccountable distinction drawn in these two states between acts and omissions was probably a by-product of the gradual emergence of negligence law from the older notions of trespass, assumpsit, and case, which was still taking place at that time. This seems particularly clear from the original Rhode Island statute, which protected the lives of passengers and of persons "in the care of" the railroad proprietors. ${ }^{101}$ The existence of an affirmative undertaking to carry safely smacks of the concept of assumpsit, and corporate responsibility seems entirely appropriate.102 But apart from some specific undertaking such as this, the desirability of imposing a general affirmative duty of care had not become sufficiently obvious to attract the attenton of the lawmakers in these states. Consequently, where assumpsit was missing the legislatures felt there must be a trespass-a wrongful act-before liability for death should attach..$^{103}$ Thus, the distinction between the requirements of the two provisions seems to stem from the fragmentary view on negligence which prevailed at that time, rather than from any desire to single out carriers for harsher treatment than other defendants.

Unfortunately (but only for the historian) there are no sig-

${ }^{100}$ The applicable sections of the North Carolina statute read as follows:

"Sec. 1. ... whenever the death of a person shall be caused hy the negligence or default of any railroad or steamboat company, or of any steamboat or stagecoach proprietor, in this State, and the neglect or default is such as would have entitled the party injured to maintain an action and recover damages in respect thereof, if death had not ensucd [sic], then and in every such case, the corporation which would have been liable if death had not ensued, shall be liable to an action for damages, notwithstanding the death of the person injured.

"Sec. 2. . . . whenever the death of a person shall be caused by the wrongful act of another person, and the wrongful act is such as would have entitled the party injured to maintain an action, and recover damages in respect thereof, if death had not ensued, then and in every such case, the person who would have been liable, if death had not ensued, shall be liable to an action for damages, notwithstanding the death of the person injured, and although the death shall have been caused under such circumstances as amount in law to felony." N.C. Pub. Laws 1854.55, ch. 39, $\S \S 1-2$, at 97 .

Both sections follow the language of Lord Campbell's Act almost verbatim, except that the English statute refers throughout to "wrongful act, neglect, or default." While the first section quoted above retains this concept, the second section conspicuously abandons it.

${ }^{101}$ R.I. Acts \& Resolves 1853, Oct. Sess., § 1 , at 257.

102 BOHLEN, The Basis of Affirmative Obligations in the Law of Tort, in STudies IN THe Law OF TORTS 33, 38-39 (1926); Prosser, TORTs $\$ 54$, at 334 (3d ed. 1964).

${ }_{102}$ Ibid. 
nificant decisions under the North Carolina statute of 1854 . The measure was superseded in 1868 by a single provision similar to Lord Campbell's Act. ${ }^{104}$

\section{Missouri, Colorado, and New Mexico}

The contradictions and inconsistencies discovered in the dual coverage acts of Kentucky, Rhode Island and North Carolina are all found again in novel rearrangement in the Missouri death statute of $1855 . .^{105}$ This act, with its treatment of carriers ${ }^{106}$ separate from other defendants in death cases, is of particular interest because it served as the model for two other states-Colorado ${ }^{107}$ and New Mexico. ${ }^{108}$ For Missouri and New Mexico the measure represented the first effort to deal with death claims. In Colorado, on the other hand, the legislature had enacted a general death statute similar to Lord Campbell's Act in 1872, ${ }^{109}$ but it unaccountably abandoned this measure in 1877 and substituted the Missouri statute with only slight modification. ${ }^{110}$ It was not until 1955 that the Missouri legislature moved to a general death act, ${ }^{111}$ and the original statutes, with some changes, still remain in effect in both Colorado ${ }^{112}$ and New Mexico. ${ }^{113}$

\footnotetext{
104 N.C. Laws 1868-69, ch. 113, $\$ \$ 70-72$, at 276 (1869).

${ }^{105}$ MO. REv. STAT. $1854-55$, ch. $51, \$ \$ 2-4$ (1855). For the text of the carrier provision of this statute see note 117 infra.

${ }^{200}$ The carrier provision of the original Missouri statute included "locomotive, car or train of cars," "steamboat, or any of the machinery thereof," and "stage-coach, or other public conveyance." Mo. REv. STAT. 1854-55, ch. 51, §2 (1855).

Although the Missouri court interpreted the section as including public motor carriers, Higgins v. St. Louis \& Suburban Ry., 197 Mo. 300, 95 S.W. 863 (1906), the legislature removed any doubt by making express reference to motor vehicles when the measure was amended in 1905. Mo. Laws $1905, \S 1$, at 135.

The original New Mexico and Colorado provisions (whicb, in this respect, are the same today) were copied verbatim from the Missouri statute, except that steamboats were appropriately excluded in these states. Both public motor cars and street railways were later included through judicial interpretation in New Mexico. Sanchez v. Contract Trucking Co., 45 N.M. 506, 117 P.2d 815 (1941). Street railways were also brought within the coverage of the carrier provision in Colorado. Friedrichs v. Denver Tramway Corp., 93 Colo. 539, 27 P.2d 497 (1933).

The Colorado and Missouri courts have held that "public conveyance" includes elevators in public buildings. Davis v. Colorado Sav. Bank, 78 Colo. 509, 242 Pac. 985 (1926); Williams v. Short, 219 Mo. App. 99, 268 S.W. 706 (1925).

${ }_{107}$ CoLO. Gen. LAws 1877, ch. 25, $\$ 877-81$.

${ }^{108}$ N.M. COMP. LAws 1884, tit. 33, ch. 23, $\$ \$ 2308-16$.

${ }^{100}$ Colo. Terr. Laws $1872, \S 1$, at 117 .

110 See note 107 supra.

111 Mo. Laws 1955, §1, at 778, Mo. ANN. STAT. $\$ \$ 537.080,537.085,537.090,537.100$

(Supp. 1964).

112 Colo. Rev. Stat. AnN. 1963, \$\$ 41-1-1-41-1-4.

${ }^{128}$ N.M. STAT. ANN. $\$ \$ 22-20-1,22-20-3$ (1953), N.M. STAT. ANN. $\$ \$ 22-20-2,22-20-4$ (Supp. 1965).
} 
1. Difference Between Sections in Amount of Award

The Missouri act, which will be referred to as the Missouri Model, shares with the Kentucky statute the approach of a combined penal measure and death act, but it reverses the Kentucky scheme. It is that portion of the Missouri Model dealing exclusively with deaths caused by the misconduct of carriers that makes provision for an award of punitive damages without proof of loss, while the general death section of the same statute provides for a compensatory award to designated beneficiaries. The amounts recoverable under the early various provisions are shown in the following table: ${ }^{114}$

Carrier

deaths

Missouri

Colorado

New Mexico

Other deaths $\$ 5,000$ penalty $\$ 3,000-\$ 5,000$ penalty $\$ 5,000$ penalty

$\begin{array}{lll}\text { Pecuniary loss } & \text { Pecuniary loss } & \text { Pecuniary loss } \\ \text { (Max. limit of } & \text { (Max. limit of } & \text { (No max. limit) } \\ \$ 5,000) & \$ 5,000) & \end{array}$

As the table clearly shows, it would be to the plaintiff's advantage to seek the carrier recovery: (1) in Missouri, in every case; (2) in Colorado, whenever it was likely that pecuniary loss to beneficaries was less than 3,000 dollars; (3) in New Mexico, whenever it was likely that pecuniary loss to beneficiaries was less than 5,000 dollars. ${ }^{115}$ For this reason limitations on the availability of the penal carrier measure were brought into sharp focus from the start.

\section{Restrictions on Resort to One Section or the Other}

In considering the strictures on the right to resort to the carrier provision of the Missouri Model, it may be recalled that in Kentucky, Rhode Island and North Carolina the representative of any person who met his death by reason of railroad operations was entitled to the benefits of the section directed against carriers. ${ }^{110}$ We have seen that the difficulty encountered in those states related solely to the limited availability of the general death provision.

${ }_{114}$ Mo. REv. STAT. 1854-55, ch. 51, $\$$ 2-4 (1855); N.M. CoMP. Laws 1884, tit. 33, ch. $23, \S \S 2308-10$, amended by N.M. Laws 1891, ch. 49, $\S 2$; Colo. Gen. Laws 1877, ch. $25, \S \S 877-79$.

${ }^{115}$ See, e.g., Clint v. Stolworthy, 144 Colo. 597, 357 P.2d 649 (1960) (recovery by child who was unable to show pecuniary loss); Denver \& R.G.R.R. v. Frederic, 57 Colo. 90, 140 Pac. 463 (1914) (under penal statute, earnings of deceased were immaterial).

${ }^{116}$ See sections A, B, C supra. 
The Missouri Model reversed this approach. The general death provision was a comprehensive measure modeled after Lord Campbell's Act. It was only when a claimant sought to enjoy the benefit of the arbitrary penal award under the carrier provision that he encountered difficulties. It is clear from the provisions of this section $^{117}$ that a recovery for death due solely to a negligent defect or insufficiency in the vehicle or its machinery could not be allowed unless the claim was on behalf of a deceased passenger. ${ }^{118}$ In the case of all other victims of fatal accidents caused by carrier fault, the claimant was obliged to show that the death resulted from the negligence, unskillfulness or criminal intent of an officer or employee who was engaged in actively running, conducting, or managing the conveyance. ${ }^{119}$ The courts in Missouri, Colorado and New Mexico

117 "Sec. 2.-Whenever any person shall die from any injury, resulting from, or occasioned by, the negligence, unskillfulness or criminal intent, of any officer, agent, servant or employee, whilst running, conducting or managing any locomotive, car or train of cars; or of any master, pilot, engineer, agent or employee, whilst running, conducting or managing any steamboat, or any of the machinery thereof; or of any driver of any stage-coach, or other public conveyance, whilst in charge of the same as a driver; and when any passenger shall die from any injury, resulting from, or occasioned by, any defect or insufficiency in any railroad, or any part thereof; or in any locomotive or car; or in any steamboat or the machinery thereof; or in any stagecoach, or other public conveyance, the corporation, individual or individuals, in whose employ any such officer, agent, servant, employee, master, pilot, engineer or driver, shall be, at the time such injury is committed, or who owns any such railroad, locomotive, car, stage-coach or other public conveyance, at the time any injury is received, resulting from or occasioned by any defect or insufficiency above declared, shall forfeit and pay for every person or passenger so dying, the sum of five thousand dollars, which may be sued for, and recovered: First, By the husband or wife of the deceased; or, Second, If there be no husband or wife, or he or she fails to sue within six months after such death, then by the minor child or children of the deceased; or, "Third, lf such deceased be a minor and unmarried, then by the father and mother, who may join in the suit, and each shall have an equal interest in the judgment; or if either of them be dead, then by the survivor. In suits instituted under this section it shall be competent for the defendant, for his defence, to show that the defect or insufficiency named in this section, was not of a negligent defect or insufficiency." Mo. REv. STAT. 1854-55, ch. 51, \$2 (1855) (emphasis added). The New Mexico and Colorado provisions, supra notes I07, 108, were similar.

${ }^{118}$ The language of the original section, supra note 117 , suggests that recovery for the death of a passenger could not be allowed unless the fatal accident was due to defective machinery or equipment, thus excluding passenger deaths caused by the active negligence of railroad employees. This was later corrected by amendment. Mo. Laws 1885, $\$ 1$, at 153 .

${ }^{110}$ The Missouri legislature drew the same distinction between active and passive negligence that had been drawn by the legislatures of Rhode Island and North Caro. lina. In the latter states the distinction placed the carrier provision in conflict with the general death provision. See text accompanying notes 91-94 and following note 99 supra. Under the Missouri Model the distinction is drawn within the carrier provision itself and served to separate the rights of passengers from those of other persons killed through railroad operations. Such justification as there may be for the 
consistently accorded this measure a strict interpretation. The families of railroad employees (who could not qualify as passengers) were consistently denied the benefits of the penal provision whenever the worker's death was attributable to defective rails, machinery or equipment. ${ }^{120}$ Claims on behalf of highway users killed at railroad intersections received similar treatment: If the death of the victim of such an accident could be charged to the inattention of the engineer or other railroad employee, a recovery of the fixed penal sum might be forthcoming. ${ }^{121}$ If, however, the accident were caused by a negligent failure on the part of the carrier to provide an adequate view of the tracks ${ }^{122}$ or to supply a sufficient number of watchmen, ${ }^{129}$ the suit, if maintainable at all, had to be prosecuted under the general death provision. Furthermore, in order to recover under the penal section it was essential to show that the death was chargeable to some risk that arose out of the operation of a public vehicle; the death of a pedestrian by electrocution due to a failure of the employees of an electric street railway to remove a fallen trolley wire could not give rise to a suit under this section. ${ }^{124}$

The respective advantages and disadvantages ensuing from resort to one section or the other of the Missouri Model were more obvious under the New Mexico version of the statute than in Missouri itself. Although the original penal railroad section in New Mexico

basic distinction is probably the same for all three states-the undeveloped state of negligence law at that time, with its requirement of a specific undertaking whenever the alleged default was a mere failure to affirmatively make conditions same. Sce text accompanying notes 101-04 supra.

${ }^{120}$ Holmes v. Hannibal \& St. J.R.R., 69 Mo. 536 (1879); Elliott v. St. Louis \& I.M.R.R., 67 Mo. 272 (1878). The same result followed where the deceased employee was off duty and riding gratuitously. Atchison, T. \& S.F.R.R. v. Headland, 18 Colo. 477, 33 Pac. 185 (1893); Higgins v. Hannibal \& St. J.R.R., 36 Mo. 418 (1865).

121 Potter v. St. Louis \& S.F.R.R., 136 Mo. App. 125, 117 S.W. 593 (1909) (engineer failed to keep lookout for persons on track); cf. Becke v. Missouri Pac. Ry., 102 Mo. 544, 13 S.W. 1053 (1890) (engineer failed to have headlight burning).

${ }_{122}$ Rapp v. St. Joseph \& I.R.R., 106 Mo. 423, 17 S.W. 487 (1891) (high weed growth obstructed view of tracks); Crumpley v. Hannibal \& St. J.R.R., 98 Mo. 34, 11 S.W. 244 (1889) (suit under penal statute must be dismissed unless failure to give signal was cause).

${ }^{128}$ Culbertson v. Metropolitan St. Ry., 140 Mo. 35, 36 S.W. 834 (1896).

124 Steyer v. United Rys., 185 S.W. 737 (Mo. Cl. App. 1916).

In at least one Missouri decision the court accorded the term "cause" a highly artificial meaning. A seriously wounded person was accepted as a passenger and died while being negligently handled. The court observed that his death was not caused by the operation of the train, within the meaning of the penal provision, since the wound was of a mortal character. Jackson v. St. Louis, I.M. \& So. Ry., 87 Mo. 422 (1885). 
authorized a flat award of 5,000 dollars, ${ }^{125}$ the general death provision in that state, unlike its counterparts in Missouri and Colorado, was not subjected to any maximum limit. ${ }^{126}$ In this state, therefore, a claimant would frequently find that it was to his advantage verdict-wise to avoid the penal provision rather than to seek its protection as in the other two states. ${ }^{127}$ The courts of New Mexi$\mathrm{co}$, however, regarded the carrier provision as the exclusive remedy for all fatal accidents falling within its coverage. ${ }^{128}$ The contrast between the remedies available became a matter of even greater moment when the New Mexico court later held that public motor vehicles, as well as trains, were embraced within the carrier provision. ${ }^{129}$ The result was highly confusing. Unlimited compensatory damages were available to the dependents of a pedestrian whose death was chargeable to carelessness on the part of the operator of a private automobile, ${ }^{130}$ while there was a maximum limitation whenever the offending vehicle happened to be a taxicab or motorbus.131 The unfortunate families of passengers killed in cabs and buses encountered the same difficulty. ${ }^{132}$

\section{Avoiding the Restrictions}

One attempt to escape these restrictions was inspired by an amendment to the Missouri railroad section in 1905, which eliminated the arbitrary award of 5,000 dollars and, following the original Colorado pattern, vested the jury with discretion to impose a penalty of not less than 2,000 nor more than 10,000 dollars. ${ }^{133}$ Thereafter, the contention was made that the Missouri statute retained its penal character only in the sense that 2,000 dollars was always available without respect to proof of loss by the beneficiaries,

\footnotetext{
${ }^{228}$ N.M. CoMp. Laws I884, tit. 33, ch. 23, \$ 2308.

${ }^{200}$ N.M. Comp. Laws 1884, tit. 33, ch. $23, \$ 2310$, amended by N.M. Laws 1891, ch. $49, \S 2$; see table accompanying note 114 supra.

227 See text accompanying note 115 supra.

${ }^{228}$ E.g., Mallory v. Pioneer Southwestern Stages, Inc., 54 F.2d 559 (10th Cir. 1931). ${ }^{280}$ Sanchez v. Contract Trucking Co., 45 N.M. 506, 117 P.2d 815 (1941).

${ }^{30}$ Cf. White v. Montoya, 46 N.M. 241, 126 P.2d 471 (1942), where the negligent driver was operating as an individual public carrier. He was, therefore, neither an officer or agent, as required by the language of the penal section; hence suit under the general death provision was appropriate.

${ }^{131}$ N.M. Laws 1882, ch. 61, § I, also cited in N.M. STAT. ANN. 1929, §36-10I; see De Soto Motor Corp. v. Stewart, 62 F.2d 914 (10th Cir. 1932). 232 N.M. Laws 1882, ch. 61, $\$ 1$, also cited in N.M. STAT. ANN. 1929, §36-101; see Mallory v. Pioneer Southwestern Stages, Inc., 54 F.2d 559 (10th Cir. 1931). 133 Mo. Laws 1905, §1, at 137.
} 
but that recovery above this figure was purely compensatory and rested upon proof of actual loss as under the general death provision, rather than upon the degree of culpability of the defendant. This argument was rejected; the Missouri court held that the carrier section remained punitive despite the amendment. ${ }^{134}$

Some of the restrictions and distinctions were subsequently alleviated. In Missouri the technicalities surrounding the carrier provision in practice did not operate to the serious disadvantage of most families of death victims: The general death provision was available and the courts manifested great liberality witl respect to proof of pecuniary loss. ${ }^{185}$ Moreover, punitive damages were recoverable under the general death provision upon a showing of gross negligence. ${ }^{136}$

New Mexico made successive increases in the penal amount to be awarded under the carrier provision, ${ }^{137}$ and ultimately the legislature in 1955 abandoned the penalty approach entirely and substituted an award of such compensatory and exemplary damages as the jury might deem fair and just. ${ }^{138}$ Under the present carrier section as thus amended, the damages appear to be assessed on the same basis as is provided by the general death measure.

\section{Problems of Beneficiaries in New Mexico}

Other complications with respect to the two competing provisions of the New Mexico statute followed as the aftermath of an amendment to the general death provision in 1891. Up until that time the beneficiaries and parties entitled to sue under both provisions of the act were the same, but the 1891 amendment made separate provision for the beneficaries entitled to recover under the general death section..$^{139}$ Included here as eligible claimants, among others, were the dependent parents of an adult unmarried child. No corresponding change, however, was made in the penal provision, and recovery under this latter section continued to be

\footnotetext{
${ }^{186}$ Grier v. Kansas City, C.C. \& St. J. Ry., 286 Mo. 523, 228 S.W. 454 (1921); sec Young v. St. Louis, I.M. \& So. Ry., 227 Mo. 307, 127 S.W. 19 (1910).

${ }_{188}$ Russell, Measure of Damages Under Missouri Wrongful Death Act, 15 Mo. L. Rev. 31 (1950). In 1945 the maximum recovery under the general death provision was finally increased to $\$ 15,000$. MO. REv. STAT. $\$ 537.090$ (1959).

${ }^{136}$ Gray v. McDonald, 104 Mo. 303, 16 S.W. 398 (1891).

${ }^{187}$ The penalty was increased to $\$ 7,500$ in $1931, N . M$. Laws 1931 , ch. $19, \S 1$, at 39 , and to $\$ 10,000$ in 1947, N.M. Laws 1947 , ch. $125, \S 1$, at 213 .

${ }^{138}$ N.M. Laws 1955, ch. 270, $\S 1$, at 727, N.M. STAT. ANN. \$22.20.4 (Supp. 1965).

${ }^{130}$ N.M. Laws 1891, ch. $49, \S 2$, at 101 .
} 
restricted to parents of minor children, who were entitled to services. As a consequence of this inconsistency, the dependent parents of an adult bus passenger were denied recovery when the latter was killed as the result of the negligent operation of the vehicle. ${ }^{140}$ The action would have been sustained under the general death measure if the victim had lost his life through carelessness of a private motorist. This state of affairs continued until 1947 when the carrier measure was finally amended to authorize suit by the personal representative even in the absence of any designated beneficiary. ${ }^{141}$ Since damages are also now assessed on the same basis for both the railroad and general death provisions, ${ }^{142}$ it appears to be irrelevant in all respects whether a claim is prosecuted under the carrier measure or under the general death statute, and hence the continued retention of the carrier provision in New Mexico is difficult to explain.

\section{E. Texas}

Of all the variations on the dual coverage theme, the Texas statute $^{143}$ involved the most serious complications for the families of death victims. This measure, which later was copied by the legislature of Arizona $^{144}$ and prevailed in that state for more than a decade, ${ }^{145}$ will be referred to as the Texas Model. As originally enacted in 1860, the staute covered in a single section both deaths occasioned by the operations of carriers and those caused by the wrongdoing of other defendants:

If the life of any person is lost by reason of the negligence or carelessness of the proprietor or proprietors, owner, charterer or hirer of any railroad, steamboat, stage-coach, or other vehicle for the conveyance of goods or passengers, or by the unfitness, gross

\footnotetext{
${ }^{160}$ Mallory v. Pioneer Southwestern Stages, Inc., 54 F.2d 559 (10th Cir. 1931) Similarly, suit under the penal section had to be instituted by the individual beneficiary, while an action under the general death provision could be maintained by the personal representative. If the personal representative brought a penal action, the suit might be dismissed, e.g., Sanchez v. Contract Trucking Co., 45 N.M. 506, 117 P.2d 815 (1941); of. Cain v. Bowlby, 114 F.2d 519 (10th Cir. 1940) (penal recovery allowed to wife who was personal representative because of her additional status as beneficiary). ${ }^{141}$ N.M. Laws 1947 , ch. $125, \S 1$, at 213 , as amended, N.M. STAT. ANN. $\$ 22-20-4$ (Supp. 1965). 163 See note 138 supra and accompanying text. ${ }^{163}$ Tex. Gen. Laws 1860 , ch. 35 , at 32 . See the exhaustive discussion in Green, The Texas Death Act, 26 TexAs L. Rev. 133 (1947).

${ }^{164}$ ARIz. REv. STAT. 1887, \$§2145-55.

${ }_{165}$ The original statute was superseded by ARIz. REv. STAT. 1901, \$§ 2764-66.
} 
negligence or carelessness of their servants or agents, and whensoever the death of a person may be caused by wrongful act, neglect, unskilfulness or default, and the act, neglect, unskilfulness or default is such as would (if death had not ensued) have entitled the party, injured, to maintain an action for such injury, then and in every such case the person who would have been liable if death had not ensued, shall be liable to an action for damages, notwithstanding the death of the person injured, and although the death shall have been caused under such circumstances as amount, in law, to a felony. . $^{146}$

Following this dual coverage measure was a section that designated the eligible beneficiaries and outlined the procedures to be followed in suits under the statute. These were the same in all particulars irrespective of whether the claim was asserted against a carrier or against some other defendant. The damages to be recovered in all instances were measured in terms of the losses to the surviving members of the family, following in this respect the approach of Lord Campbell's Act. ${ }^{147}$

It will be observed from the language of the original Texas Model that although the measure was not penal in character, the provision for deaths occasioned by the misconduct of carrier employees required that gross negligence be established. In this respect the Texas Model followed the approach of Massachusetts and other New England states. ${ }^{148}$ The Texas legislature, however, changed this provision in 1887 to allow recovery for ordinary negligence on the part of carrier employees ${ }^{149}$ - a modification that was not effected in Massachusetts until 1907.150 Following this change, a Texas death claimant would encounter little difficulty whenever his suit could be so framed as to fit the carrier provision.

${ }^{166}$ Tex. Gen. Laws 1860, ch. 35, § 1, at 32. In Tex. Rev. Stat. 1879, tit. 52, at 419, the carrier provision and the general death provision appear as separate, connective subsections.

${ }^{147}$ Tex. Gen. Laws 1860, ch. 35, § 2, at 33 .

${ }^{148}$ See text accompanying notes 37 and 53 supra.

140 Tex. Gen. Laws 1887, ch. 62, $\S 1$, at 44 . Prior to this amendment the Texas courts consistently denied recovery where gross negligence was not shown. San Antonio St. Ry. v. Cailloutte, 79 Tex. 341, 15 S.W. 390 (1891); Missouri Pac. Ry. v. Brown, 75 Tex. 267, 12 S.W. 1117 (1889); Dallas City R.R. v. Beeman, 74 Tex. 291, 11 S.W. 1102 (1889); Sabine \& E. Tex. Ry. v. Hanks, 73 Tex. 323, 11 S.W. 377 (1889); Texas \& Pac. Ry. v. Hill, 71 Tex. 451, 9 S.W. 351 (1888).

${ }^{180}$ Mass. Acts \& Resolves 1907, ch. 375, § I, at 324; Mass. Acts \& Resolves 1907, ch. $392, \S 1$, at 338 . See text accompanying note 49 supra. 


\section{Respondeat Superior Liability}

The general death provision of the Texas Model, when considered apart from the remainder of the section, would appear to offer no difficulty. It was not restricted to deaths occasioned by willful misconduct, as in Kentucky, ${ }^{151}$ nor was the right to recover limited to deaths caused by acts, as in Rhode Island and North Carolina. ${ }^{162}$ The Texas Model, however, provided specifically in the carrier provision for deaths attributable to the misconduct of employees, while no corresponding express provision existed in the short, general death phrase..$^{153}$ This absence of conformity in the language of the two provisions invited the contention that the death measure was limited to fatalities occasioned by the defendant's personal misconduct whenever the latter was not a railroad or other carrier. This argument prevailed in the leading Texas case of Hendrick $v$. Walton. ${ }^{154}$ In that decision the supreme court conceded that if the general death provision stood alone, "the maxim that what one does for another he does himself," would be applicable to a death claim. ${ }^{155}$ It concluded, however, that when the legislature made express provision for respondeat superior liability in suits against carriers and omitted any corresponding provision with reference to other employers it must have intended that a distinction be drawn. ${ }^{\mathbf{1 5 6}}$

\footnotetext{
${ }^{251}$ See text accompanying note 69 and following note 70 supra.

${ }^{152}$ See text accompanying notes 91 and 94 and following note 99 supra.

${ }^{153}$ Sce text accompanying note 146 supra.

154 69 Tex. 192, 6 S.W. 749 (1887).

${ }^{155} \mathrm{Id}$. at $195,6 \mathrm{S.W}$. at 750 .

${ }^{250}$ The same contention was made to the courts in Missouri and New Mexico, but was rejected. Gray v. McDonald, 104 Mo. 303, I6 S.W. 398 (1891); Hogsett v. Hanna, 41 N.M. 22, 63 P.2d 540 (1936). The rationale used shows the seriousness with which the matter was regarded.

To escape the contention, both courts felt obliged to characterize their general death provisions as survival measures. For example, in Gray v. McDonald, supra, the Missouri court observed: "This section ... does not, as is often supposed, create a new cause of action; it transmits to the designated persons a cause of action where the injured person would have had one, had death not ensued. In other words, the cause of action does not abate by reason of the death of the person injured." 104 Mo. at 311 , I6 S.W. at 400 . Thus, since the benefits of respondeat superior would have been available to the deceased, they were available to the representative, who inherited all his rights. This same rationale was followed by New Mexico in Hogsett v. Hanna, supra.

But the price of this resolution of the problem was high. Distortion of the general death provision ensued in both jurisdictions. The Missouri Supreme Court previously had properly characterized the general death provision as analogous to Lord Campbell's Act, conferring a new cause of action upon the representative at death. Entwhistle v. Feighner, 60 Mo. 214, 215 (1875) ("[a claim under the general death provision] .... is an action in which plaintiff and defendant only could be parties, for it did not arise
} 
The court fortified this conclusion by pointing out that in the original statute of 1860 , carriers were liable only for the gross negligence of their employees, and that an application of respondeat superior under the general death provision would produce the anomalous result of subjecting all employers except carriers to liability for the ordinary negligence of their workers, thus evidencing a preference of carrier enterprises. ${ }^{157}$ This argument, however, is considerably weakened by the fact that the requirement of gross negligence had already been deleted from the carrier provision by the time of the Hendrick decision. ${ }^{158}$

There is an impressive line of Texas decisions reaffirming the position taken in Hendrick $v$. Walton. ${ }^{159}$ Corporate liability was still possible under the general death provision, ${ }^{160}$ but only when the conduct of the corporation itself was unlawful or when there was wrongdoing by a vice-principal in the course of directing the conduct of the company's business. ${ }^{161}$ Even under these circumstances the

until after the husband's death."). But as a result of Gray v. McDonald, supra, the Missouri decisions fell into a state of conflict which ended only in the 1926 decision of State ex rel. Thomas v. Daues, 314 Mo. 13, 283 S.W. 51 (1926), which affirmed the wrongful death character of the statute.

The New Mexico Supreme Court, having once adopted the reasoning of Gray v. McDonald, supra, adhered faithfully thereafter to its commitment to the survival theory. As late as 1952 it held, in the face of a blistering dissent, that a cause of action under the general death provision arises at the time of injury, rather than at the time of death, since the death claim must be regarded as a mere continuation of the victim's own rights. Natseway v. Jojola, 56 N.M. 793, 251 P.2d 274 (1952). It was not until 1961 that the New Mexico legislature amended the general provision so as to confirm its character as a wrongful death statute, at least with respect to the statute of limitations. N.M. Laws 1961, ch. 202 , $\S 1$, at 673 , N.M. STAт. ANN. $§ 22 \cdot 20 \cdot 2$ (Supp. 1965).

${ }_{157} 69$ Tex. at 196, 6 S.W. at 750.

${ }^{158}$ See note 149 supra and accompanying text.

${ }^{150}$ E.g., Hargrave v. Vaughn \& Cumming, 82 Tex. 347, 18 S.W. 695 (1891) (druggist not liable for child's death attributed to clerk's negligence in selling poison to parent; suggestion that clerk might be personally liable).

${ }^{160}$ Fleming v. Texas Loan Agency, 87 Tex. 238, 27 S.W. 126 (1894).

${ }^{102}$ Hugo, Schmeltzer \& Co. v. Paiz, 104 Tex. 563, 567.68, 141 S.W. 518, 520.21 (1911) (employer liable for death of employee killed as result of negligent directions given by foreman or supervisor; the court imported the vice-principal doctrine from cases involving the fellow servant rule).

Cf. Sullivan-Sanford Lumber Co. v. Cooper, 105 Tex. 21, 142 S.W. 1168 (1912), which illustrates the highly restrictive attitude of the court in such cases. Decensed, an employee in a sawmill, was directed to do work under the floor of the mill. While he was so engaged, defendant's foreman ordered another worker to perform a task at a place in close proximity to the valve of a steam-operated machine. The machinery was set in motion when the valve was inadvertently pressed by the worker's elbow, resulting in the death of the deceased beneath the floor. Id. at 24-26, 142 S.W. at 1169-70. The death claim was based upon the negligence of the foreman in ordering an inexperienced employee to work in the immediate vicinity of the valve without 
Texas court refused the benefits of the general death measure where the defendant was a municipal corporation, reasoning that a public entity, unlike a private corporation, did not fall within the coverage of the provision. ${ }^{102}$

\section{Resort to the Carrier Provision}

The position adopted by Texas in Hendrick $v$. Walton, which served to confer virtual immunity against death claims upon all corporate defendants except carriers, naturally had the effect of focusing the attention of litigants upon the carrier provision, where the benefit of respondeat superior remained available. It will be noted that the language of the carrier provision embraced not only railroads and steamboats, but also "other vehicle[s] for the conveyance of goods or passengers ...." ."163 The Texas court refused, however, to classify an elevator in a public building as such a "vehicle,"164 although both Missouri and Colorado later so held. ${ }^{165}$ The Texas result was reached by pointing out that the legislature could not have contemplated inclusion of elevators within the statute, since they were not in existence when it was enacted in $1860.166 \quad \mathrm{~A}$ similar determination of legislative intent led to the rejection of a claim against an express company under the carrier provision for the death of a person who was shot by its watchman while acting within the scope of his employment. ${ }^{167}$

In 1913 the Texas legislature amended the general death provision to impose liability upon all corporations for deaths resulting from the negligence of their servants, ${ }^{108}$ thus abrogating the holding

instruction. Id. at 24, I42 S.W. at 1169. Recovery under the general death provision was denied since the foreman did not instruct the worker to press the valve. Id. at 28-29, $142 \mathrm{~S} . \mathrm{W}$. at 1171 . Ordering an inexperienced worker to do a job where his inadvertence would result in injury to others, thought the court, may serve to avoid the fellow servant rule, but it would not meet the strictures of the language of the general death act. See id. at 29-30, 142 S.W. at 1172.

${ }_{102}$ Elliott v. City of Brownwood, 106 Tex. 292, 166 S.W. 1129 (1914). Similarly, it was held that a receiver of a railway was not a "proprietor" within the meaning of the carrier provision. Turner v. Cross \& Eddy, 83 Tex. 218, 18 S.W. 578 (1892). Thereafter receivers were brought within the purview of the statute by amendment. Tex. Gen. Laws 1892, Ist Sess., ch. 7, §1, at 5 .

${ }^{108}$ See text accompanying note 146 supra.

104 Farmers' \& Mechanics' Nat'l Bank v. Hanks, 104 Tex. 320, 328-29, 137 S.W. 1120, 1125 (1911).

${ }^{205}$ Davis v. Colorado Sav. Bank, 78 Colo. 509, 242 Pac. 985 (1926); Williams v. Short, 219 Mo. App. 99, 268 S.W. 706 (1925).

${ }^{100}$ Farmers' \& Mechanics' Nat'l Bank v. Hanks, 104 Tex. 320, 328-29, 137 S.W. 1120,1125 (1911).

${ }^{107}$ Lipscomb v. Houston \& Tex. Cent. Ry., 95 Tex. 5, 64 S.W. 923 (1901).

${ }^{108}$ Tex. Gen. Laws 1913, ch. 143, at 288. 
in Hendrick v. Walton. In Hamilton v. St. Louis, S.F. \& Tex. $R y .{ }^{169}$ however, this amendment was held invalid because of defects in its title. Finally, in 192I, the Texas statute was completely overhauled by the legislature, ${ }^{170}$ and respondeat superior liability was imposed on all defendants.

\section{Other Carrier Provision Problems}

Lipscomb v. Houston \& Tex. Cent. Ry..$^{171}$ held that a railroad employer was liable when its watchman, acting within the scope of his employment, shot and killed the decedent. It is not clear, however, that the Texas court would correspondingly extend the protection of the carrier provision to similar risks not readily and immediately associated with transportation activities. In Missouri, $K$. \& T. Ry. v. Freeman, ${ }^{172}$ for example, recovery was denied where the railroad's surgeon carelessly detained a patient, who then communicated small pox to the decedent.

For many years confusion persisted in Texas on whether the provision for death liability directed to the proprietors of any railroad, steamboat "or other vehicle for the conveyance of goods or passengers"173 was restricted to common carriers, or extended to those transporting their own goods in commerce. Although the issue was not brought sharply into focus in the earlier decisions, their general tenor clearly suggests that only those who offered their transportation services to the public at large were included.174 In several later cases, however, liability under the above provision was imposed upon the operators of railroads used solely in connection with lumbering and other industrial activities conducted by their owners. ${ }^{175}$ In 1926 the issue was finally put to rest in favor of the broader coverage by Hamilton v. St. Louis, S.F. \& Tex. Ry.176 The court held that the carrier provision embraced a death resulting from

\footnotetext{
100115 Tex. 455, 283 S.W. 475 (1926).

170 Tex. Gen. Laws 1921, ch. 109, at 212, Tex. Rev. Crv. StAt. ANN. art. 4671 (1952).

17195 Tex. 5, 64 S.W. 923 (1901).

17297 Tex. 394, 79 S.W. 9 (1904).

178 See text accompanying note 146 supra.

174 See cases collected and discussed in Hamilton v. St. Louis, S.F. \& Tex. Ry., 115 Tex. 455, 466-68, 283 S.W. 475, 478--79 (1926).

${ }^{175}$ Sullivan-Sanford Lumber Co. v. Watson, 106 Tex. 4, 155 S.W. 179 (1913) (private railroad owned by lumber company); Cunningham v. Neal, 101 Tex. 338, 107 S.W. 539 (1908) (private railroad owned by sugar and paper mill); cf. Farmers' \& Mechanics' Nat'l Bank v. Hanks, 104 Tex. 320, 328, 137 S.W. 1120, 1124-25 (1911) (dictuin that statute might cover private property).

${ }^{176} 115$ Tex. 455, 283 S.W. 475 (1926).
} 
the negligent operation of a truck belonging to a petroleum company which was being used at the time for the transportation of its own products. ${ }^{177}$ There was no indication, however, that a private motor vehicle used for non-business purposes would be similarly covered.

\section{General Revision}

In 1921, the Texas legislature completely revised the death statute. ${ }^{178}$ The language of the present statute, which is patterned basically on the model of Lord Campbell's Act, serves as a reminder of the complex and unrealistic state of the law that preceded its enactment. The legislature, in an earnest effort to avoid for the future all the complexities that had formerly beset the death law of Texas, undertook to spell out each earlier deficiency and to obviate it specifically. Although the resulting statute, which is presently in force, is a cumbersome and repetitious measure, there can remain little doubt as to the comprehensive scope of its coverage.

\section{F. Arizona}

Fortunately, the Arizona version of the Texas Model was of short life. It was repealed fourteen years after its enactment in 1887, and a measure similar to Lord Campbell's Act substituted for it. ${ }^{179}$ The earlier statute was in effect long enough, however, to afford the Arizona Supreme Court an opportunity to follow the Texas decision in Hendrick $v$. Walton, thus denying to plaintiffs the benefit of respondeat superior in all Arizona death claims against defendants who did not qualify under the carrier provision. ${ }^{180}$

\section{G. The Dakotas}

The final variation of a dual coverage statute was enacted for the Dakota Territory in 1874..$^{181}$ The first section of this measure, authorizing a recovery where death was caused by the negligence of railroads or their employees, was a survival statute which empowered the personal representative to recover damages "in the same manner that the [deceased] person might have done for any injury where

${ }^{177}$ Id. at $468 \cdot 69,283$ S.W. at 479.

${ }^{178}$ Tex. Gen. Laws 1921, ch. 109, at 212, Tex. REv. Crv. Stat. ANN. art. 4671 (1952).

${ }^{170}$ ARIZ. REV. STAT. 1901, \$§ 2764-66.

${ }^{180}$ Don Yan v. Ah You, 4 Ariz. 109, 77 Pac. 618 (1893).

181 DAKOTA TERR. LAws 1874, ch. 54, at 217 (1875). Almost identical provisions appear in 1 Dakota Terr. Rev. Codes ANN. 1883, $\$ \S 676-77$. 
death did not ensue."182 Recovery under this provision was denied where the death was instantaneous. ${ }^{183}$ The second section of the Dakota death statute was comprehensive in coverage and extended to deaths caused by the negligence of all persons and corporations, and included servants. ${ }^{184}$ The right of recovery was vested in the widow, heir, or personal representative. ${ }^{185}$

This latter section as originally enacted in 1874 authorized the recovery of "punitive damages for the loss or destruction of the life aforesaid."186 Thirteen years later, however, the term "punitive" was stricken from the statute. ${ }^{187}$ Thereafter, the general death provision was regarded by the courts as analogous to Lord Campbell's Act, under which damages were assessed in terms of the losses suffered by the beneficiaries. ${ }^{188}$

The Dakota courts applied the general death measure to deaths caused by railroad operations, ${ }^{189}$ with the result that where the defendant was a railroad, both the wrongful death remedy and a suit under the survivorship theory of the first section were available. Against other defendants, however, the claimant was restricted to damages caused by the death, and there could be no recovery of

182 "If the life of any person, not in the employment of a railroad corporation, shall be lost, in this territory, by the reason of the negligence or carelessness of the pro. prietor or proprietors of any railroad, or by the unfitness or negligence or carclessness of their employes or agents, the personal representatives of the person whose life is so lost, may institute suit and recover damages in the same manner that the person might have done for any injury where death did not ensue." 1 DAkota TEIR. REv. CODES ANN. 1883, $\$ 676$. (Emphasis added.)

${ }^{183}$ Belding v. Black Hills \& Ft. P.R.R., 3 S.D. 369, 53 N.W. 750 (1892).

284 "If the life of any person or persons is lost or destroyed by the neglect, carelessness, or unskillfulness of another person or persons, company or companies, corporation or corporation [sic], their or his agents, or servants or employes, then the widow, heir, or personal representatives of the deceased shall have the right to suc such person or persons, company or companies, corporation or corporations, and recover punitive damages for the loss or destruction of the life aforesaid." 1 DAkorA TERr. REv. CODES ANN. 1883, §677.

${ }^{185}$ Sec note 184 supra.

${ }^{188}$ Dakota TERR. LAwS 1874, ch. 54, §2, at 217 (1875).

${ }^{187}$ Dakota TerR. LAws 1887 , ch. $27, \S 1$, at 69 .

${ }^{188}$ Haug v. Great No. Ry., 8 N.D. 23, 77 N.W. 97 (1898) (pecuniary loss presumed where claimant was wife or minor child of deceased); Smith v. Chicago, M. \& St. P. Ry., 6 S.D. 583, 62, N.W. 967 (1895) (damages restricted to pecuniary loss; nondependent parent of adult child denied recovery); Belding v. Black Hills \& Ft. P.R.R., 3 S.D. 369, 53 N.W. 750 (1892) (widow treated as having preferred rights to recover under general death section).

${ }^{180}$ The possibility that the survival provision might be the exclusive remedy in suits against railroads appears never to have been considered by the courts. Note that all the cases under present discussion involved claims against railroads. 
damages that accrued prior thereto. 190 The Dakota dual coverage provision remained in effect in North Dakota until 1895, when it was superseded by a single provision for wrongful death that tracked the language of Lord Campbell's Act. ${ }^{191}$ In South Dakota the original measure was not abandoned in favor of a wrongful death statute until 1909.192

\section{IV}

\section{Railroad Death Agts Enacted After General Death Acts}

We have seen that many of the special provisions for death inflicted by railroads were regarded as independent measures that coexisted side by side with general death provisions and were in frequent conflict with the latter. This, however, was not to be true of two states, Michigan and Connecticut, which had death provisions of general application already in effect when the legislatures undertook to enact special statutes with reference to railroad deaths.

\section{A. Michigan}

As early as 1838 the Michigan legislature had provided for the survival of claims for assault, battery, and imprisonment. ${ }^{103}$ Ten years later it adopted a death statute phrased in language almost identical to that of Lord Campbell's Act.194 With these two mea-

\footnotetext{
200 Provision was ultimately made for the survival of all personal injury claims in North Dakota in 1949, N.D. Laws 1949, ch. 213, § I, at 277, N.D. CENT. CODE § 28-01-26.1 (1960), and in South Dakota in 1951, S.D. Laws 1951, ch. 186, $\S \S 1-2$, at 196, S.D. CoDE $\$ 33.0414$-I (Supp. 1960). Cf. Ulvig v. McKennan Hosp., 56 S.D. 509, 229 N.W. 383 (1930) (no recovery for pain and suffering of child burned to death through negligence of hospital).

201 N.D. REv. CoDes 1895, §§5974-77, as amended, N.D. CENT. CoDE § 32-21-01 (1960).

102 S.D. Laws 1909, ch. 301, at 497, as amended, S.D. CODE $\$ \S 37.2201-.2203$ (Supp. 1960), Rowe v. Richards, 32 S.D. 66, 142 N.W. 664 (1913) (dual coverage statute repealed by implication with enactment of general death statutes).

${ }^{203}$ Mich. Rev. STAT. pt. 3, tit. 2, ch. 3, $\$ 7$ (1838); see text accompanying note 9 supra.

104 "Section 1. Whenever the death of a person shall be caused by wrongful act, neglect or default, and the act, neglect or default is such as would, (if death had not ensued,) have entitled the party injured to main an action, and recover damages, in respect thereof, then and in every such case, the person who, or the corporation which would have been liable, if death had not ensued, shall be liable to an action for damages, notwithstanding the death of the person injured, and although the death shall have been caused under such circumstances as amount in law to felony.

"Section 2. Every such action shall be brought by, and in the names of the personal representatives of such deceased person, and the amount recovered in every such action shall be for the exclusive benefit of the widow and next of kin of such deceased person, and shall be distributed to such widow and next of kin in the proportions provided by law in relation to the distribution of personal property, left by persons dying intestate; and in every such action, the jury may give such damages
} 
sures already in force the legislature nevertheless undertook in 1855 to make special provision for railroad deaths in Michigan's first general railroad incorporation statute. ${ }^{195}$ This death measure duplicated the earlier death statute in every respect, except that "railroad company or its agents" was used to designate the party whose act, neglect or default would give rise to the death action, and damages recoverable were limited to 5,000 dollars.

In 1873 the railroad provision was amended by striking out the limitation on the amount recoverable and by omitting the limitation to "pecuniary injuries" which had appeared in the original railroad measure, and which continued to appear in the general death statute. ${ }^{106}$ This single resulting inconsistency between the two acts inevitably resulted in litigation. In Van Brunt $v$. Cincinnati, J. b. M.R.R., ${ }^{107}$ suit was brought by a non-dependent father for the death of an adult son killed by the defendant railroad. The claimant contended that the legislature of 1872 , in removing the 5,000 dollar limitation and omitting the former express restriction to pecuniary damages, intended that damages assessed against railroads should be whatever the jury might deem "fair and just." 198 The court rejected this contention, stating that an assessment of damages against railroads on a basis different from that which would prevail in death suits against other defendants would be class legislation, which the court did not believe the legislature had intended. ${ }^{199}$

The Van Brunt decision resulted in a requirement of demonstrable pecuniary loss under both the railroad statute and the general death act, thus robbing the former measure of any apparent justification. Nevertheless, the railroad death act remained in effect. Finally, in 1951, the court held that the measure had been repealed by implication when both the general death act and the Michigan survival statute were substantially amended and consolidated in $1939 .{ }^{200}$

as they shall deem fair and just, with reference to the pecuniary injury resulting from such death, to the wife and next of kin of such deceased person." Mich. Laws 1848, No. $38, \S \S 1-2$, at 31 .

108 Mich. Laws 1855, No. $82, \S \S 54-55$, at 176.

${ }^{108} 1$ Mich. Laws 1873 , No. 198 , art. $5, \S \S 7.8$, at 496 .

18778 Mich. 530, 44 N.W. 321 (1889).

${ }^{108} I d$. at 535, 44 N.T. at 322 .

${ }^{199}$ Id. at $537-38,44$ N.W. at 323.

${ }^{200}$ Mich. Pub. \& Local Acts 1939, No. 297, at 687, Mich. STAт. ANN. \$§ 27.711-.718 (1962), Southward v. Wabash R.R., 331 Mich. 138, 49 N.TV.2d 109 (1951). 


\section{B. Connecticut}

It will be recalled that the legislature in Connecticut in 1848 provided for the survival of all personal injury claims without qualication. ${ }^{201}$ This measure had been successfully employed as a remedy in fatal railroad accidents. ${ }^{202}$ In Murphy v. New York, N.H. \& H.R.R. ${ }^{203}$ the Connecticut court extended the statute to cover even instantaneous deaths. In so doing the court treated the death itself as an injury to the deceased that deprived him of all prospective earnings. It thus prepared the way for use of the survival statute as the exclusive vehicle for recovery in fatal accident cases in Connecticut.

Nevertheless, in 1853 Connecticut enacted a railroad death statute. ${ }^{20 t}$ This measure was limited to claims on behalf of deceased passengers and persons killed at highway crossings. It authorized an award of 1,000 to 5,000 dollars, to be recovered by the administrator. The measure included a provision for the distribution of the proceeds of the judgment. Shortly after the enactment of this statute, the Connecticut court was faced with a situation in which the sole beneficiary died soon after the decease of the railroad victim; $;^{205}$ hence the pain and suffering of the deceased between the time of accident and death constituted the chief item of damages that could be recovered. It was argued that there could be no award for these damages under the special railroad provision. ${ }^{206}$ The court, however, held that damages for pain and suffering were justifiable under the survival statute even though the claimant had placed no reliance on this measure. ${ }^{207}$ In so deciding the court declined to hold either that the special statute and the survival measure afforded separate cumulative remedies, or that the defendant should elect which he would pursue, or that the railroad death act was the ex-

201 Conn. Acts 1848 , ch. $5, \S 2$, at 7, also cited in Conn. Rev. STat. 1849, ch. 6, $\$ 82$, at 72 .

${ }^{202}$ Soule v. New York \& N.H.R.R., 24 Conn. 575 (1856).

${ }^{208} 30$ Conn. 184 (1861).

sos Coun. Pub. Acts 1853 , ch. 74, §8, at 135. In 1869 this act was supplemented by a statute requiring the construction and maintenance of fences along railroad rights of way, with similar remedial provisions. Conn. Pub. Acts 1869 , ch. 48, $\$ \$ 1-2$, at 235 .

An earlier statute, directing the sounding of the highway crossing signal by railroads, imposed an arbitrary penalty of $\$ 1000$ for death of any person killed through a violation. The penalty was payable to the widow and children of the victim, or, in their default, to the nearest relative of the deceased. Conn. Pub. Acts 1851, ch. 43, $\S 2$, at 43 . This statute was repealed in 1877 . Conn. Pub. Acts 1877, ch. 78, $\$ 2$, at 192.

${ }^{205}$ Goodsell v. Hartford \& N.H.R.R., 33 Conn. 51 (1865).

200 Id. at 52.

${ }^{207} I d$. at 55 . 
clusive remedy with reference to deaths falling within the scope of its coverage. Instead, the court regarded the special statute as a mere specification of the survival measure..$^{208}$ As such, this special provision therefore merely provided a limitation on the amount to be recovered under the survival act against railroad defendants, coupled with an arbitrary provision for the distribution of the proceeds of recovery in suits against this one class of defendants. ${ }^{200}$ Thus the railroad statute became amalgamated into the survival measure. 210

Despite this situation, the Connecticut legislature continued to tolerate the coexistence of the two acts. In 1872 the provision for the distribution of proceeds, which formerly appeared only in the railroad act, was incorporated verbatim into the survival statute.211 The limitation on the amount recoverable, however, remained a feature of the railroad statute alone. This last inconsistency between the two measures could have been removed either by expunging the limitation on damages from the special act or by imposing a similar limitation with respect to the survival measure. Neither alternative, however, was adopted by the Connecticut lawmakers. Instead, the legislature in 1877 enacted in place of the former railroad statute a new death section of general application, which provided that "in all actions by an executor or administrator for damages resulting in death from negligence" the executor or administrator might recover "just damages not exceeding five thousand dollars." 212 The measure further provided that these damages should be distributed as provided in the amended survival statute. This method of distribution, as we have seen, had been taken over into the survival measure from the original railroad statute. Thus, both features which had distinguished the old railroad act became incorporated in what appeared on the surface to be a new, independent death statute of general application, and which, arguably, was now a potential competitor with the established survival statute.

We have seen, however, that from the very beginning the Connecticut courts had taken a broad view of the protection afforded by the survival statute of 1848 . In making this measure available in

${ }^{208} I d$. at 56.

200 Ibid.

${ }^{810}$ But cf. Andrews v. Fartford \& N.F.R.R., 34 Conn. 57 (1867) (under railway act of 1853 cause of action did not arise until death of victim).

211 Conn. Pub. Acts 1872, ch. 69, at 40 .

212 Conn. Pub. Acts 1877, ch. 78, §1, at 191. 
cases of instantaneous death, it had committed itself to the theory that the death was a wrong to the victim himself and that the damages to be recovered should be measured in terms of the loss of the victim's earnings from the time of accident until the expiration of his normal life expectancy. ${ }^{213}$ Even the estimated living expenses of the deceased during this period were not to be deducted in arriving at the amount of the award to his administrator. ${ }^{214}$ When this state of the Connecticut case law on survivorship is borne in mind, it becomes obvious that no second and cumulative remedy for death could be tolerated without facing the prospect of substantial double recovery. To escape this dilemma, the courts interpreted the 1877 amendment just as the original railroad death statute had been interpreted-as a mere specification of the survival measure, imposing a limitation on the amount recoverable and designating the beneficiaries to whom the proceeds of the judgment under the survival statute should be distributed. ${ }^{215}$ This attack upon the problem has persisted, and although the statutes have been altered in several respects, ${ }^{216}$ the survival theory of recovery for wrongful death prevails even today in Connecticut.

\section{$\mathrm{V}$}

\section{Other Spectal Death Acts}

Although Michigan and Connecticut represent the only significant instances in which the legislatures undertook to introduce special railroad death provisions into comprehensive schemes which were already in operation, ${ }^{217}$ there were a few legislative efforts to

\footnotetext{
${ }^{213}$ Kling v. Torello, 87 Conn. 301, 87 Atl. 987 (1913).

ax، See Chase v. Fitzgerald, 132 Conn. 461,45 A.2d 789 (1946) (full review of authorities; court repudiates statement in earlier Connecticut decisions suggesting that lost accumulations to estate furnish proper measure of damages).

215 See Porpora v. City of New Haven, 122 Conn. 80, 86-93, 187 Atl. 668, 671-73 (1936), which reviews the complicated shifting of provisions between the survival statute and the "death act" of 1877. According to the opinion there was a short period of one year, following the revision of 1902, ConN. REv. STAT. 1902, §§399, 1094, when the survival measure was eliminated by absorption into the "death act." Survival was restored in 1903, Conn. Pub. Acts 1903, ch. 149, at 114. See also Comment, 22 CoNN. B.J. 404, 407 n.15 (1948). The limitation on the overall amount recoverable was increased to $\$ 20,000$ by the legislature in three successive stages and finally eliminated entirely in 1951. CoNN. GEN. STAt. REv. § 1392b (Supp. 1951). Despite the survival character of the Connecticut statute, the proceeds are not subject to the claims of general creditors. See ConN. GEN. STAT. REv. § 1305e (Supp. 1939).

${ }_{210}$ The present provisions of the Connecticut wrongful death statutes are CoNN. GeN. Stat. REv. §§ 52-555, 52-599, 45-280 (1958).

${ }^{217}$ Brief reference should be made to the earliest Georgia effort at death legisla-
} 
single out other special situations for distinct treatment in the face of preexisting statutes of general application. In 1895, thirty-six years after the adoption of a general death statute, ${ }^{218}$ the constitution of South Carolina was amended to include a penal provision authorizing an award of not less than 2,000 dollars against any county in which a lynching took place, "without regard to the conduct of the officers," in favor of the legal representative of any person killed by such mob action. ${ }^{210}$ Provision was made for recovery over by the county against the actual participants. ${ }^{220}$ This was followed the next year by similar action in Ohio, ${ }^{221}$ where a general death provision had been on the statute books for forty-five years. ${ }^{222}$ Both special statutes remain in effect today. ${ }^{223}$

\section{VI}

\section{The Employers' Liability Movement: Further Confusion IN Death Statutes}

The last two decades of the nineteenth century ushered in a wave of legislative reform affecting the rights of employees to recover for injuries resulting from negligence of employers or of fellow employees. Most of the earlier measures of this kind did little more than afford a legislative recognition of the vice-principal or superior-

tion. In 1850 the legislature enacted a death act with general coverage, Ga. Stat. 1850, No. 83, at 476 (Cobb 1851). This measure merely authorized suit by the administrator whenever the deceased could have maintained an action, and it directed that half of the proceeds be paid to the wife and children in the event of the estate's being insolvent. It is difficult to determine whether the measure should be regarded as a death statute or as a provision for survival, and no occasion arose for a clarification by the courts during the brief period of its existence. Cf. SouthWestern R.R. v. Paulk, 24 Ga. 356 (1858). Six years thereafter the legislature passed an equally cryptic statute directed exclusively toward deaths occasioned by the negligence of railroad companies or their employees. Ga. Laws 1855.56, No. 106, $\$ 4$, at 155 (1856). No suit was ever instituted pursuant to this mcasure. In 1863 both statutes were superseded by a single measure of general coverage known as the Homicide Act, which served as the nucleus for the present Georgia death statute. GA. CODE 1863, §2913 (1933), as amended, GA. CODE ANN. $\$ \S 105-1301$ to -1310 , as amended, Ga. Code ANN. §105-1306 (Supp. 1963). Sce Southern Bell Tel. \& Tel. Co. v. Cassin, 111 Ga. 575, 600-11, 36 S.E. 881, 891-95 (1900) (dissenting opinion).

218 S.C. Acts $1857-59$, No. 4480 , at 825 (1859).

${ }^{210}$ S.C. Const. art. VI, $\$ 6$.

220 S.C. CoNsT. art. VI, $\S 6$. This constitutional provision was implemented by S.C. 4cts 1896, No. 94, at 213 .

22192 Ohio Laws $\$ \S 5-12$, at 137 (1896).

22249 Ohio Laws 117 (1851).

${ }^{223}$ OHIo Rev. Code ANN. $\$ \$ 3761.04-3761.10$ (Page 1954); S.C. CoNST. art. VI, § 6; S.C. CODE ANN. $\$ 10.1961$ (1962). 
servant doctrine and, in some instances, of the separate-departmentof-work rule. Furthermore, the benefits of the first American statutes of this sort were generally confined to employees of railroads, and occasionally mines. ${ }^{224}$

Since the only purpose of such legislation was to abolish or modify certain employer defenses that had existed at common law, there was no sound reason why these measures should disturb the existing pattern of general death legislation, which merely conferred a right to recover in case of death whenever the deceased could have recovered if the injury had not been fatal.225 The majority of the early employers' liability statutes proceeded on this premise. Some of the measures mentioned only employee injuries, ${ }^{226}$ others referred to both injuries and death, ${ }^{227}$ while still others contained express language indicating that if the employee were killed, recovery should be secured through resort to the established death statutes. ${ }^{228}$ Usually

226 See generally Dodd, Administration of Workmen's Compensation 11-16 (1936). The statutes prior to 1913 are listed and analyzed in 5 LABATt, MASTER AND SERvant (2d ed. 1913).

${ }_{220}$ Philo v. Illinois Cent. R.R., 33 Iowa 47 (1871); Ean v. Chicago, M. \& St. P. Ry., 95 Wis. 69, 69 N.W. 997 (1897); Gumz v. Chicago, St. P. \& M. Ry., 52 Wis. 672, 10 N.W. II (1881) (by implication); see Vickers v. Board of County Comm'rs, 59 Kan. 86, 52 Pac. 73 (1898); Racho v. City of Detroit, 90 Mich. 92, 51 N.W. 360 (1892); Merkle v. Township of Bennington, 58 Mich. 156, 24 N.W. 776 (1885); Eames v. Town of. Brattleboro, $54 \mathrm{Vt}$. 471 (1882).

220 Fla. Laws 1891, ch. $4071, \S 3$, at 114 (repealing Fla. Laws 1887, ch. $3744, \S 2$, at 117); Ga. Laws 1856, No. 103, $\$ 3$, at 155; GA. CoDE 1873, $\$ 3036$; Iowa Laws 1862, ch. $169, \$ 7$, at 198; Iowa Laws 1872, ch. 65, at 70; Kan. Laws 1874, ch. 93, at 143; Minn. Laws 1887, ch. 13, at 69; MiNN. Rev. LAws 1905, §2042; Mont. Terr. Laws 1873, $\$ 20$, at 104; N.D. Laws 1903, ch. 131, at 178; Ohio Laws 1890, $\$ 2$, at 149; Okla. Laws 1907, ch. 53, $\$$, at 520; Pa. Laws 1907, No. 329, at 523; Utah Laws 1896, ch. 24, at 99; Wis. Laws 1880, ch. 232, at 270 (repealing WIs. REv. STAT. 1878, \$ 1816, which had reworded Wis. Laws 1875 , ch. 173, $\S 1$, at 293); Wis. Laws 1889, ch. 438, at 613; Wis. Laws 1903, ch. 448 , at 741 (rewording Wis. Laws 1893, ch. 220, $\$ 1$, at 268).

${ }_{227}$ Ark. Acts 1893, ch. 46, at 68; Ark. Acts 1907, No. 69, at 162; Ind. Acts 1907, ch. 118, § 14, at 190; Kan. Laws 1907, cb. 281, §1, at 454; N.C. Priv. Laws 1897, ch. 56, $\S 1$, at 83; Ohio Laws 1890, $\$$, at 149; Ohio Gen. Code 1910, \$6242; Tex. Gen. Laws 1891 , ch. 24 , at 25.

${ }^{228}$ Colo. Laws 1893, ch. 7 , $\$ 1(3)$, at 129 (employee has same rights as if he were not an employee), Colorado Milling \& Elevator Co. v. Mitchell, 26 Colo. 284, 58 Pac. 28 (1899); Ind. Laws 1893, ch. 130, $\$ 3$, at 295 (express reference to "the law now in force"); N.J. Laws 1909, ch. 83, $\$ 1(3)$, at 114 (employee has same rights as if he were not an employee); 2 N.Y. Laws 1902, ch. 600, 1 (2), at 1749 (express reference); S.C. Const. art. 9, $\$ 15$ (1895) (employee has same rights as if he were not an employee; limited to railroad employees); Vt. Laws 1910, No. 97, $\$ 1$, at 101 (employee has same rights as if he were not an employee; limited to railroad employees); VA. ConsT. $\$ 162$ (1902), Va. Laws 1901-02, ch. 322, at 335 (1902) (separate, right of action given to railroad employees is not to interfere with other rights); Wyo. Terr. Laws 1869, ch. 65 , at 433 (employee has same rights as if he were not an employee; limited to railroad employees). 
no difficulty was encountered by the courts when the statutes were of the types indicated above. ${ }^{229}$ However, the supreme court of at least one jurisdiction, Missouri, adopted the position that the employers' liability act of that state ${ }^{230}$ conferred only a personal right upon the employee which would not be embraced under the earlier death statutes of the state if he were killed.231 Thereafter the Missouri legislature was obliged to amend the death statute so as to include specifically "an employe ... whose death is caused by the negligence of a co-employe ...."232

The legislatures in a large group of states (Alabama, Illinois, Idaho, Indiana, Maine, Mississippi, Montana, Oregon and Vermont), possibly in anticipation of a holding such as that of the Missouri court, made special, and sometimes elaborate, provision for death suits in their respective employers' liability statutes. In nearly every instance these measures differed in one respect or another from the then prevailing general death statute; and whenever the deceased employee's own cause of action would depend upon an employers' liability statute, his surviving family or administrator was forced to ignore the general death measure and accept the procedures and benefits provided by the special act. ${ }^{233}$

220 See note 225 supra.

230 Mo. Laws 1897, §§ 1-4, at 96.

${ }^{231}$ Strottman v. St. Louis, I.M. \& So. Ry., 211 Mo. 227, 252-258, 109 S.W. 769, 775-777 (1908). Four years later the Missouri court in a carefully considered opinion repudiated this decision. Hawkins v. Smith, 242 Mo. 688, 147 S.W. 1042 (1912).

232 Mo. Laws $1905, \S 1$, at 136.

${ }^{333}$ In the following paragraphs the situation is described at tbe time of tbe cnactment of the special act. In many instances subsequent modifications of the death statutes or the special acts have obviated or modified the discrepancies.

Alabama: The first Alabama provision establishing the vice-principal rule, Ala. Acts 1884-85, No. 51, at 115 (1885), was so drawn as to present no confiict with the general death statute of the state, Ala. Acts 1871-72, No. 62, at 83 (1872). The Alabama Supreme Court so held in Stewart v. Louisville \& N.R.R., 83 Ala. 493, 4 So. 373 (1888). A second general Alabama death statute, Ala. Acts 1884-85, No. 36, at 99 (1885), authorized a parent to sue for the death of a child. Where the child was an employee with the consent of the father, however, the court held that suit could be maintained only by the representative under the employers' liability act. Williams v. South \& No. Ala. R.R., 91 Ala. 635, 9 So. 77 (1891); Lovell v. DeBardelaben Coal \& Iron Co., 90 Ala. 13, 7 So. 756 (1890).

Idaho: In 1909 the Idaho legislature adopted a measure modifying the fellowservant rule and abrogating the assumption-of-risk doctrine for specific employments under limited circumstances. Idaho Laws 1909 , at 34 . This statute required in $\$ 5$ that notice be given the employer within 150 days following the death, and $\$ 4$ limited damages to $\$ 5,000$. These provisions did not appear in the general death act, IDAHo REv. CoDEs 1908, $\S 4100$.

The Idaho courts have had little occasion to refer to the employers' liability 
statute. Where, for example, suit was brought under the general death act, the Idaho Supreme Court rejected the employer's argument that the notice provision of the employers' liability act had not been met, stating that the latter act "did not repeal or abrogate any existing law with reference to the right of recovery by the heirs or legal representatives of a deceased person for an injury causing the death of such person." Chiara v. Stewart Mining Co., 24 Idaho 473, 479, 135 Pac. 245, 246 (1913).

Illinois \& Indiana: The Illinois statute regulating the operation of mines created a cause of action for employee injurics or deaths occasioned by a willful violation of its provisions. III. Pub. Laws 1871, $\$ 14$, at 574, also cited in ILL. REv. Stat. 1874, ch. $93, \S 14$, at 708 . Suit was to be instituted by the widow or other designated beneficiaries in their individual capacities, while the prevailing Illinois death statute of the same period authorized suit only by the administrator. Ill. Gen. Laws 1853 , §2, at 97, also cited in IL.. REv. STAT. 1874, ch. 70, 2 , at 582 . In Litchfield Coal Co. v. Taylor, 81 Ill. 590, 592 (1876), a suit brought by the administrator under the mining statute was dismissed. In Bradley v. Chicago-Virden Coal Co., 231 III. 622, 83 N.E. 424 (1908), the designated claimant was shifted three times during the litigation in order to include or exclude the claim from the mining law, until finally all rights were barred by the statute of limitations.

The same confiicts existed between the Indiana mining act, Ind. Laws 1891, ch. 49, at 57 , and the Indiana death act, Ind. Laws 1881 , ch. $38, \$ 8$, at 241 , also cited in IND. StaT. ANN. \$285 (Burns 1894). The administrator could not sue under the mining act. Maule Coal Co. v. Parthenheimer, 155 Ind. 100, 55 N.E. 751 (1900); Collins Coal Co. v. Hadley, 38 Ind. App. 637, 643, 75 N.E. 832, 833 (1906). Cf. Couchman v. Prather, 162 Ind. 250,70 N.E. 240 (1904), where suit by the administrator under the death act was dismissed because a special statute covering damages from the illegal sale of intoxicants, 3 IND. STAT. ANN. $\$ 7288$ (Burns 1901), provided for suit by "any person who shall sustain any injury or damage to his . . . means of support."

Maine \& Vermont: Compare the Maine employers' liability act, Me. Laws 1909, ch. 258, at 336, modeled after the English statute of 1880 , to $\$ 9$ and $\S 10$ of the prevailing Maine general death statute of the same period, ME. REv. StaT. 1903, ch. 89, at 784. The Maine death statute had been interpreted to apply only in cases of instantaneous death. Sawyer v. Perry, 88 Me. 42, 33 Atl. 660 (1895). In the employers' liability act, express provision was made for both instantaneous and noninstantaneous death, Me. Laws 1909 , ch. 258, $§ \S 2-3$, at 336 .

Both the Vermont employers' liability statute, Vt. Laws 1910, No. 97, at 101, and the Vermont death statute, Vr. PUB. STAT. 1906, $\$ \$ 2839-40$, were similar to the corresponding Maine provisions. The gencral death acts of both states were almost verbatim copies of Lord Campbell's Act, and provided that damages should be assessed in terms of the losses suffered by the beneficiaries. The employers' liability statutes in both states, however, directed that damages for death be assessed "with reference to the degree of culpability of the employer or of the person for whose negligence the employer is liable." Me. Laws 1909, ch. 258, §4, at 337; Vt. Laws 1910, No. 97, $\S 5$, at 102. The two statutes in each state also differed with respect to the beneficiaries, the persons entitled to institute the suit, and the distribution of the proceeds.

Mississippi: The first statute of this state establishing the vice-principal doctrine and the separate-department-of-work rule, Miss. Laws 1896, ch. 87, at 97, set up a complete scheme for the maintenance of suits for employee deaths. This statute differed from the general death statute passed during the same session, Miss. Laws 1896, ch. 86, at 96, with respect to beneficiaries, the method of assessing damages, and the distribution of the judgment proceeds. See Bussey v. Gulf \& S.I.R.R., 79 Miss. 597, 31 So. 212 (1902) (despite differences between statutes, employers' statute did not pre-empt general death statute as to employees).

Montana: Montana statutes in 1905 abrogated the fellow-servant rule for railroad employees, Mont. Laws 1905, ch. $1, \S 1$, at 1 , and for mine employees, Mont. Laws 1905 , ch. $23, \S 1$, at 51 . The railroad provision in $\S 2$ and the mine provision in $\S 3$ 
Shortly after 1908 a new wave of state legislation for the protection of railroad workers emerged as a result of the enactment of the Federal Employers' Liability Act. ${ }^{234}$ The aim of Congress in this latter measure was to abolish the fellow-servant rule, to substitute comparative negligence for contributory negligence, and to soften the rigors of the assumed-risk doctrine. ${ }^{235}$ To effectuate these policies, Congress realized it had to face the death problem in a federal context. Federal common law denied any cause of action

stated that the employee's cause of action should survive to the personal representative or heirs. At this time Montana's general death statute was similar to Lord Campbell's Act. See II MONT. REv. CoDEs 1907, $\$ 6486$. Thus if death were instantaneous, the general death statute would provide a remedy, but the railroad and mine statutes would not. Therefore if recovery depended upon the measure abolishing the fellows-servant rule and death was instantaneous, no recovery was possible. Dillon v. Great No. R.R., 38 Mont. 485, 492-93, 100 Pac. 960, 962 (1909).

An interesting and complicated variation of the Montana picture was presented to the Appellate Division of the New York Supreme Court. Prior to the enactment of the 1905 Montana railroad statute, which completely abolished the fellow-servant rule, there was in effect a 1903 statute which modified the fellow-servant rule by desig. nating certain railroad employees who were not to be regarded as fellow-servants, Mont. Laws 1903, ch. 83, $\$ 1$, at 156. This latter statute contained no death provision, thereby bringing the general death statute of Montana into operation. In Storrs v. Northern Pac. Ry., 148 App. Div. 403, 132 N.Y. Supp. 954 (1911), a worker was killed after the effective date of the 1905 statute, but his death resulted from the negligence of one of the superior servants included within the coverage of the 1903 measure. Id. at 409, 132 N.Y. Supp. at 958-59. The New York court, applying Montana law, held that the general death statute was applicable, although if the negligent co-worker had been one other than a superior servant, tbc only remedy would have been survivorship under the 1905 act. Ibid.

Oregon: In 1910 the people of Oregon by initiative enacted a measure imposing rery exacting duties on contractors for the benefit of their workers. See Ore. Gen. Laws 1911 , ch. 3, at 16 . The death provision of this measure, $\S 4$, provided expressly that damages for death should be without limitation, while the general death pro. vision then in force, Ore. Gen. Laws $1907, \mathrm{ch} .72$, at 128 , also cited in 1 Ore. LAws $\$ 380$ (Lord 1910), provided for a maximum limit of $\$ 7,500$. The Oregon Supreme Court held in Cameron v. Pacific Lime \& Gypsum Co., 73 Ore. 510, 144 Pac. 446 (1914), that the $\$ 7,500$ limit was therefore not applicable in a case brought under the special statute.

Recovery under the special statute was to be sought directly by the designated beneficiaries, while the general death statute authorized a proceeding by the personal representative only. If none of the designated beneficiaries existed, the personal rcpresentative could still sue under the general death statute, but subject to the $\$ 7,500$ limit. Niemi v. Stanley Smith Lumber Co., 77 Ore. 221, 147 Pac. 532, affirmance rev'd on rehearing, 77 Ore. 221, 149 Pac. 1033 (1915). Damages for dcath under the gen. eral statute were measured during this period in terms of loss of accumulations to the estatc. See Hansen v. Hayes, 175 Ore. 358, 379, 154 P.2d 202, 210 (1944).

The Oregon legislature in 1903 adopted a measure establishing tbe superiorservant rule for railroad employees. Ore. Laws 1903, $\$ 1-2$, at 20 . In contrast to the special contractors' liability statute, the short provision in this measurc for employee deaths was consistent with the general death act.

236 35 Stat. 65 (1908), as amended, 45 U.S.C. \$\$ 51-60 (1964).

${ }^{285}$ See Doherty, Liability of RaIlroads to INTERSTATE EMIPLoyees 39.44 (1911). 
for wrongful death, ${ }^{236}$ and hence a specific death provision was necessary to protect the families of deceased workers. Consequently, the Federal Employers' Liability Act was equipped with a death provision $^{237}$ similar to Lord Campbell's Act. The personal representative was authorized to sue for the death on behalf of designated beneficiaries, who were established in preferred and deferred categories. The suit was "for the benefit of the surviving widow or husband and children of such employee; and, if none, then of such employee's parents; and, if none, then of the next of kin dependent upon such employee . . . ."238 There was no express provision for the distribution of the proceeds of judgment; neither was there any limitation upon the amount to be recovered. The statute did require, however, that the suit be commenced within two years from the date the cause of action accrued. ${ }^{239}$ Two years later, in 1910, a survival provision was added, which permitted the inclusion of damages for the pain and suffering of the deceased and for his pecuniary losses up until the time of death..$^{240}$

The federal statute by its terms applied only to railroad employees who were injured or killed while they were actively engaged in interstate commerce, ${ }^{241}$ thus leaving a large segment of railroad employee accidents untouched. In view of this limited reach of federal coverage, the state legislatures were urged to enact similar statutes to protect railroad workers against accidents that fell outside the ambit of the federal measure. In so doing, the state legislatures were free to provide for death in such manner as they saw fit. Since in every instance there were existing state death statutes available, the lawmakers might easily have either omitted all references to death or omitted entirely that portion of the federal act providing a death remedy, thus referring the procedure to the appropriate

${ }^{* 36}$ The United States Supreme Court in Insurance Co. v. Brame, 95 U.S. 754 (1877), committed itself to the doctrine of Baker v. Bolton, 1 Camp. 493,170 Eng. Rep. 1033 (K.B. 1808).

${ }_{237} 35$ Stat. 65, § I (1908), as amended, 45 U.S.C. $\$ 51$ (1964).

23835 Stat. 65, $\$ 1$ (1908), as amended, 45 U.S.C. $\$ 51$ (1964).

${ }^{280}$ Section 6,35 Stat. 66 (1908). This was changed to 3 years by Act of Aug. 11, $1939, \S 2,53$ Stat. 1404 , as amended, 45 U.S.C. $\$ 56$ (1964).

${ }_{240}$ Act of April 5, 1910, $\$ 2,36$ Stat. 291, 45 U.S.C. $\$ 59$ (1964), St. Louis, I.M. \& So. Ry. v. Craft, 237 U.S. 648 (1915).

${ }^{341}$ The constitutionality of the act was established in Second Employers' Liability Cases, 223 U.S. 1 (1912). An earlier effort by Congress to subject all carriers engaged in interstate commerce to the provisions of a similar act, Act of June 11, 1906, ch. 3073, 34 Stat. 232, was held unconstitutional in The Employers' Liability Cases, 207 U.S. 463 (1908). 
general death act of the state. ${ }^{242}$ However, in only two jurisdictions, Ohio $^{243}$ and Wisconsin, ${ }^{244}$ was the state employers' liability act brought into complete conformity with the existing state death pattern. Instead, the death provisions of the parent federal statute were generally incorporated verbatim into the so-called little federal employers' liability acts. Conformity was thus achieved with respect to interstate and intrastate railroad employee deaths, but only at the price of further disrupting the state's own statutory death scheme. ${ }^{215}$

262 This was the approach of some of the earlier liability statutes. See notes 226-28 supra and accompanying text.

243 OHIO GEN. CODE 1910, $\S 9013,9016-18$, Pittsburg, C.C. \& St. L. Ry. v. Francis, 32 Ohio C.C. Dec. 189 (Cir. C. 1910), aff'd mem., 83 Ohio St. 520, 94 N.E. 1118 (1911).

24: Wis. Laws 1907, ch. 254, at 903 (text of act at 495).

${ }^{265}$ In the following paragraphs the situation is described as it existed at the time of the enactment of the state's railroad employers' liability act. In many instances subsequent modifications of the death statutes, or occasionally the employers' liability measures, have obviated or modified the discrepancies. It should also be noted that some of the state employers' liability statutes were not restricted to railroad employce accidents.

The only distinction between the following statutes and those included in note $\mathbf{2 3 3}$ supra, is that those listed here were obviously inspired by the Federal Employers' Liability Act.

Alaska: 'The employers' liability act of this state, Alaska Laws 1913, ch. 45, at 84, contained the same provision for distribution of judgment procecds that was included in the Federal Employers' Liability Act. The Alaskan death statute prevailing at the time, Act of June 6, 1900, ch. 37, $\$ 353,31$ Stat. 392, however, provided that the proceeds of recovery in a death action should be distributed as if they were unbequeathed assets in the hands of the administrator, or, under certain conditions, as personal property of the decedent.

Up until 1955 damages under the gencral wrongful death act were measured in terms of the loss of accumulations that deceased would have left to his estate had he reached normal life expectancy. Alaska Laws 1955, ch. 153, at 315 . See discussion in Kreidler v. Ketchikan Spruce Mills, 10 Alaska 365 (1943).

Arizona: The situation here is particularly complex. In 1912 the Arizona legis. lature enacted an elective workmen's compensation statute, Ariz. Laws 1912, Spec. Sess., ch. 14, at 23, also cited in ARIz. REv. Srat. $\$ \$ 3163-79$ (Pattec 1913), and also passed an employers' liability act covering all hazardous occupations, Ariz. Laws 1912, ch. 89, at 491, also cited in ARIZ. REv. STAT. $\$ \S 3153.62$ (Pattce 1913). This latter statute was a hybrid. Unlike a workmen's compensation statute, it provided for an award of general damages for both injury and death, but like a workmen's compensation statute, it allowed recovery even if the employer was not at fault, provided that the employee was not himself negligent. Ariz. Laws 1912 , ch. $89, \S 6$, at 493 , also cited in ArIz. REv. STAT. \$3158 (Pattee 1913).

Section 6 also provided in case of death that if there was a surviving spouse or children, the personal representative should bring suit, but if not, the employec's parents should bring suit, and that the recovery was for the benefit first of spouse and children, then parents, and then dependent next of kin. The death act prevailing at this time, ARIz. REv. STAT. $\$ 3373$ (Pattee 1913), stated that the personal representative should institute suit and "the amount recovered in every such action shall be distributed to the parties and in the proportions provided by law in rela. tion to the distribution of personal estate left by persons dying intestate." $C f$. Bryan 
v. Inspiration Consolidated Copper Co., 23 Ariz. 541, 544-45, 205 Pac. 904, 905 (1922), where the intricacies of the employers' liability act confused even a "distinguished practitioner."

Arkansas: The employers' liability act, Ark. Acts 1911, No. 88, at 55, was copied almost verbatim from the Federal Employers' Liability Act. The provisions concerning bencficiaries and distribution differed substantially from those of Arkansas' then prevailing wrongful death act, Ark. Acts 1883, No. 53, $\S 2$, at 76. The supreme court of the state held that the distribution provisions of the 1911 act should control whenever the death fell within its coverage. Faulkner v. Faulkner, 186 Ark. 1082, 57 S.W.2d 818 (1933); Murphy v. Province, 153 Ark. 240, 240 S.W. 421 (1922).

Colorado: In 1937 the Colorado Icgislature cnacted a railroad employees' statute, Colo. Laws 1937, ch. 136, at 512, which incorporated much of the language of the Federal Employers' Liabihity Act, but which went beyond the federal measure in several respects: Assumption of risk was completely abolished under the Colorado measure, Colo. Laws 1937, ch. 136, $\S 3$, at 513. This was not done under the Federal Employers' Liability Act until 1939, Act of Aug. 11, 1939, § 1, 53 Stat. 1404, 45 U.S.C. $\$ 54$ (1964). Under the provisions of the 1937 Colorado statute questions of both cause-in-fact and proximate cause were to be for the exclusive determination of the jury, Colo. Laws 1937, ch. 136, $\$ 4$, at 513 .

It may be recalled that at this time Colorado maintained two separate death statutes. See section III D of this article supra. One of these, relating exclusivcly to deaths inflicted by public carriers, was strictly a penal measure, while the other, relating to all other defendants, was similar to Lord Campbell's Act. The 1937 cmployers' liability statute differed in its death provisions from both measures. For example, $\S$ I provided for liability "in case of the death of such employe, to his or her personal representative for the benefit of the surviving widow, or husband, children, parents, or dependents of such employe ...."

District of Columbia: The Federal Employers' Liability Act is by its terms made expressly applicable to injurics and deaths occurring in the District of Columbia. Section 2, 35 Stat. 65 (1908), 45 U.S.C. $\$ 52$ (1964). The general death act prevailing in the district in 1908 established no priorities among beneficiaries and ordered damages to be dispensed according to the statute of distributions. Act of March 3, 1901 , ch. 854, §1303, 31 Stat. 1395.

Georgia: The employers' liability act of this state, Ga. Acts 1909, No. 289, at 160, also cited in GA. Crv. CoDE 1910, $\$ \$ 2782-87$, generally followed the Federal Employers' liability Act. The general death act then prevailing, GA. Crv. CoDE 1910, $\$ 4424$, authorized a suit by a mother for the death of a dependent child. In Williams v. Western \& AtI. R.R., 142 Ga. 696, 83 S.E. 525 (1914), the supreme court of the state dismissed a suit by a mother for the death of a child employed by the defendant railroad, holding that the employers' liability act prevailed over the general death statute, and hence that suit must be brought by the personal representative.

Michigan: In 1909 the legislature adopted a railroad employers' liability statute, Mich. Acts 1909, No. 104, at 210, modeled in nearly every respect after the Federal Employers' Liability Act. This statute in $\$ 1$ included the federal provisions for suit by the personal representative and established virtually the same preference order for claimants as that of the federal measure. Section 6 of the Michigan act, however, provided in substance that none of its provisions should impair the rights of employees under existing state law. At the time of the enactment of the railroad measure the Michigan courts regarded claims for all noninstantaneous deaths as actionable exclusively under the Michigan survival statute, while claims for instantaneous death gave rise to a suit under the state's general death act. Dolson v. Lakeshore \&: Mich. So. Ry., 128 Mich. 444, 87 N.W. 629 (1901).

The first question to arise in Michigan was whether the death provision of the employers' liability statute should be regarded as establishing a new and distinct approach to the death problem or whether railroad employee deaths should be assimilated under the prevailing dichotomy of instantaneous versus noninstantaneous 
death. The latter approach was adopted in Habitz v. Wabash R.R., 170 Mich. 71, 77-78, 135 N.W. 827, 830 (1912), where the court held the survival measures was not available to the plaintiff, and that, since death was not instantaneous, full recovery could be had for the deceased's loss of earnings through the period of his normal life expectancy, as allowed by the doctrine of Olivier v. Houghton Co. St.-Ry., 138 Mich. 242, 101 N.W. 530 (1904). "The obvious purpose [of the Michigan employers' liability act] $\ldots$ is to change the common-law rules as to liability of common carrier railroads and not to interfere with or change the measure of damages as already fixed by existing law." Fernette v. Pere Marquette R.R., 175 Mich. 653, 672, 141 N.W. 1084, 1091 (1913) (dictum). When, however, the death of a railroad employce was occasioned during the course of an interstate railroad operation, thus forcing resort to the Federal Employers' Liability Act, the Michigan court held that the death provisions of the federal statute, including the measure of damages thereunder, should be interpreted in accordance with federal decisions, even though the language of the federal measure is similar to that of the Michigan statute. Jorgensen v. Grand Rapids \& Ind. Ry., 189 Mich. 537, 540-43, 155 N.W. 535, 536-47 (1915).

Minnesota: In 1915 the Minnesota legislature adopted an employers' liability statute which was modeled in nearly every respect after the amended Federal Em. ployers' Liability Act. The survival provision of the original Minnesota act, however, directed that the beneficiaries themselves, rather than the representative, should bring suit. Minn. Laws 1915 , ch. $187, \S 7$, at 254 . This discrepancy was removed by Minn. Laws 1923, ch. $333, \S 3$, at 486 . At the time of the enactment of this measure the Minnesota general wrongfuI death statute, which was the only remedy available in the event of death, was modeled after Lord Campbell's Act. It provided a maximum recovery of $\$ 7,500$ for the benefit of designated beneficiaries. MinN. REv. Laws 1905, $\S 4503$, amended by Minn. Laws 1911, ch. 281, at 395, also cited in MiNN. GeN. Stat. $\$ 8175$ (Tiffany 1913). Other discrepancies are discussed in Note, 6 MinN. L. REv. 584 (1922). It is also noteworthy that apart from the employers' liability act there was no provision for survival in Minnesota.

The Minnesota courts have held consistently that whenever a cause of action falls within the purview of the 1915 statute the death provisions of that statute alone shall control. E.g., Lombard v. Northern Pac. Ry., 160 Minn. I, 199 N.W. 887 (1924) (\$7,500 limitation on damages under general death statute did not apply in suit under employers' liability act); $c f$. Edelbrock v. Minneapolis, St. P. \& S. Ste. M. Ry., 166 Minn. 1, 206 N.W. 945 (1926) (plaintiff can plead both statutes and recover if either is found to be applicabIe), 10 MiNN. L. REv. 417 (1926).

Nebraska: The situation in Nebraska is similar to that in Alaska, Arizona, and Arkansas. The prevailing death act provided for suit by the representative, and for distribution of the judgment proceeds according to the law of descent. NEB. Comp. Stat. 1905, ch. 21, at 101, amended by Neb. Laws 1907, ch. 47 , at 190 . The empIoyers' liability act of the state established the same death procedure as under the Federal Employers' Liability Act. Neb. Laws 1907, ch. 48, §1, at 191.

New Mexico: Up untiI 1955 the New Mexico statutory provision that would be most nearly applicable to the death of a railroad employee was the 1882 act appearing in N.M. Comp. LAws 1884, tit. 33, ch. 23, $\$ \S 2308-16$. See section III D of this article supra. As amended by N.M. Laws 1891, ch. $42, \S 2$, it authorized a penal action for $\$ 5,000$ for the death of any person killed by a railroad. The New Mexico Supreme Court had held, however, that this measure did not abrogate the common law fellow-servant rule. Lutz v. Atlantic \& Pac. R.R., 6 N.M. 496, 30 Pac. 912 (1892).

In 1911 the voters of New Mexico ratified a constitutional provision which made railroads liable for injuries and deaths of employees caused by the negligence of fellow workers. N.M. ConsT. art. XX, $\S 16$. It included an express provision for death that tracked the language of the Federal Employers' Liability Act. Thus the family of a railroad worker killed through the negligence of a fellow employee would recelve general damages without limitation, while any other person killed through the operation of a railroad had to seck the $\$ 5,000$ penal award. The constitutional provision also 


\section{CONCLUSION}

The pattern of legislative inconsistencies and distortions described in the foregoing pages affords only a partial picture of the overall American scene of the past century. Most of the earlier troubles have been ironed out through later amendments or repeals. Moreover, most of our state legislatures resisted from the outset all temptation to deal separately with death suits against public carriers or to afford separate treatment for the deaths of workers killed through the negligence of fellow servants. In most instances, a single legislative attack was initiated against all wrongful deaths, howsoever caused. But even in these states the theory or approach adopted, however, uniformly it might be applied throughout the entire jurisdiction was frequently conceived in haste by the lawmakers and tended to break down when placed into practical operation. Too often there was imposed upon the statutory structure an agglomerate of judicial patchwork as courts attempted to obscure the problems or to reconcile the irreconcilable. The need to evolve a single adequate and realistic approach for the handling of wrongful death has proffered a baffling challenge to legislatures and courts for more than a century, and in many instances the complete answer is yet to be found. The quest for a theory will be discussed in the second and concluding installment of this study of the history of American fatal accident law.

provided different beneficiaries and a different method of distribution of judgment proceeds than the then prevailing general wrongful death act of New Mexico, N.M. Comp. Laws 1897 , tit. 33 , ch. 23 , $\$ 2315$.

North Dakota: The general death act prevailing in North Dakota in 1915 was similar to Lord Campbell's Act, and provided for suit by the individual beneficiaries designated in the statute. 2 N.D. Comp. Laws 1913, ch. 39, $\$ 8323$. There was no general provision for the survival of personal injury claims in North Dakota at that time. In 1915 the state adopted an employers' liability act almost identical to the federal statute, including the survival provision. N.D. Laws 1915, ch. 207, at 311 .

South Dakota: The South Dakota statute of 1911, S.D. Laws 1911, ch. 206, $\S 1-7$, at 294, is very similar to the federal statute. It differs from the then prevailing death statute, S.D. Sess. Laws 1909 , ch. 301, at 497 , less sharply than in some other states. Under $\$ 3$ of the South Dakota death statute the parents and next of kin of the deceased constitute a single grouping, and there is no express requirement that these claimants establish their dependency upon the deceased. This agrees with $\S 1$ of the employers' liability statute, except that under it next of kin must show dependency. However, $\S 3$ of the general death act imposes a limitation of $\$ 10,000$ on the amount recoverable while no limitation is found in the employers' liability act. 